\title{
Implementation of Pushover Analysis for Seismic Assessment of Masonry Towers: Issues and Practical Recommendations
}

\author{
Rafael Shehu
}

Citation: Shehu, R. Implementation of Pushover Analysis for Seismic Assessment of Masonry Towers: Issues and Practical

Recommendations. Buildings 2021, 11 71. https://doi.org/10.3390/ buildings11020071

Academic Editor: Rita Bento

Received: 5 January 2021

Accepted: 12 February 2021

Published: 16 February 2021

Publisher's Note: MDPI stays neutra with regard to jurisdictional claims in published maps and institutional affiliations.

Copyright: (C) 2021 by the author. Licensee MDPI, Basel, Switzerland. This article is an open access article distributed under the terms and conditions of the Creative Commons Attribution (CC BY) license (https:// creativecommons.org/licenses/by/ $4.0 /)$.
Department of Civil and Environmental Engineering, Politecnico Di Milano, 20133 Milan, Italy rafael.shehu@polimi.it

\begin{abstract}
Seismic assessment is a paramount issue and a valuable instrument towards the conservation of vulnerable structures in seismic prone regions. The past seismic events have highlighted the vulnerability of masonry towers that is exhibited by severe structural and nonstructural damages or even collapses. The preservation of existing structures, mainly focused on the built heritage, is emerging and imposing substantial enhancements of numerical methods, including pushover analysis approaches. The accuracy of the estimated seismic capacity for these structures is correlated with the assumed strategies and approximations made during the numerical modeling. The present paper concerns those aspects by exploring the limitations and possibilities of conceiving pushover analysis in the finite element method environment. The most crucial target is tracing in a pushover capacity curve the corresponding initiation of structural damages, maximum load-bearing capacity, and the ultimate displacement capacity. Different recommendations for achieving this target have been proposed and illustrated for practical utilization. Three representative geometrical towers, adopting three different materials and five different load patterns, are investigated in this study. The load pattern's role and necessity of the displacement-like control approach for the pushover analysis are exploited. This paper highlights the load-bearing capacity overestimation when the force-controlled are implemented. The material model influences the achievement of softening branch with a distinguishable displacement capacity.
\end{abstract}

Keywords: masonry structures; towers; seismic assessment; pushover analysis

\section{Introduction}

Seismic assessment is becoming an obligatory procedure for existing structures in seismic regions and, in particular, those with a high level of expected seismic risk. Many factors of the construction typology, material deterioration, and the nature of earthquakes make their capacity estimation quite uncertain. A relatively low level of seismic safety characterizes the built stock as compared to the in-force earthquake engineering practice requirements. When considering that many structures of the built stock belong to the historical and architectural heritage, it is mandatory to utilize advanced and accurate approaches [1-6]. The objects of this paper are masonry towers, typical bell towers, fortresses, or chimneys. However, the practitioners can extend many of the treated aspects of numerical procedures to a vast range of structural topologies while considering the similarities and the generalist approach of pushover analyses implementation.

Masonry towers are very peculiar structural typologies, and they are typically conceived to withstand only vertical loads, as it occurs for all historical masonry constructions [7-16]. Therefore, their seismic vulnerability is expected to be high and particular attention should be paid to their seismic assessment toward a preservation approach. Two are the main aspects that lead to an expected high vulnerability, respectively, the masonry material's poor mechanical properties in tension and the geometric features like slenderness, irregularities, and openings. Additionally, the soil-structure interaction, inclination, and adjacent structures have a significant influence on their structural response. Some 
of these features highlight a limited capacity of simplified global approaches, like those prescribed in the Guideline for Cultural Heritage Seismic Assessment (DPCM) [17], for addressing the complexity of the tower's response. Regardless of the analytical methodology, a fundamental task is the estimation of the uncertain parameters (both material properties and boundary conditions) affecting the structural behavior [18-21]. A multidisciplinary approach by means of advanced investigations and simulations is deemed to be mostly recommended aiming to identify the possible active failure modes during seismic events [22-31]. A comprehensive approach to seismic safety would include a process from diagnostic investigations to advanced numerical simulations, including out-of-plane local analyses.

This research focuses on pushover analysis as a widely used approach in the seismic assessment of masonry towers. Geometrical features and structural regularity are favorable for the successful application of nonlinear static methods, but besides that, the limitations of pushover analysis in masonry structures are well-known by the scientific community [32-39]. The numerical procedure requires the definitions of many parameters, like the material model, model mesh refinement, applied load distribution pattern, etc. Consequently, the results are directly affected by the chosen parameters. The key issue in the accuracy of pushover methods is the nature of the lateral load applied, which is whether a force or a displacement [40].

Herein, it is not claimed to address all of the aspects above because it would require investigating a larger number of case studies. The geometry and the material properties selection in this research are based on a broad research practice. The focus is on different approaches that a nonlinear static analysis could be conceived in any FEM software package. The influence of geometry, material properties, and load pattern is investigated. In this study, the simulations are performed with the Abaqus CAE software [41], which provides a wide variety of modeling options for simulating the nonlinearity of masonry structures. Some key aspects of addressing the seismic assessment of masonry towers have been gathered from the simulations. The found remarks may be easily implemented by practitioners or researchers in order to obtain more accurate and realistic results.

\section{Pushover Analysis}

Pushover analysis is a very utilized approach in earthquake engineering and one of the most accurate tools for estimating structure's seismic safety, either new or existing ones. Thenceforth, a correct implementation is essential and it should meet many criteria. There exist many approaches on the implementation and application of pushover analysis considering, (i) different load patterns [42-44]; (ii) the inclusion of higher modes [45]; (iii) adaptive load patterns [46]; and (iv) force vs. displacement control [40], etc., aiming to obtain a capacity curve that would mimic more realistically the seismic behavior of the structure. It is a common approach that is adopted by many practices to consider the pushover analysis as completed if the capacity curve is determined for values of the controlled displacement ranging between zero and the value corresponding to $150 \%$ of the target displacement [43]. Another approach is to consider the capacity until the reduction of at least $15 \%$, the maximum obtained base shear [44]. When considering that a brittle failure is very prone in typical masonry structures, it should be expected that a realistic behavior of the simulations should exhibit an apparent softening behavior. The role of numerical simulations in this regard becomes very crucial. The peculiarity of the masonry material, with a relatively low tensile strength and brittle failure in shear, makes the overall modeling and analysis process not an easy task [32].

\subsection{Load Patterns}

This section describes different load patterns that could be used in a pushover analysis. They influence the seismic assessment of the structures in terms of the pushover capacity curve shape, as will be discussed in the following sections. Five different load patterns have been considered for the simulations, see Figure 1. These load patterns are familiar 
for the readers, as they are adopted by several technical codes $[43,47,48]$ and widely applied for masonry towers. For simplicity, this article adopts the following names for each load pattern.

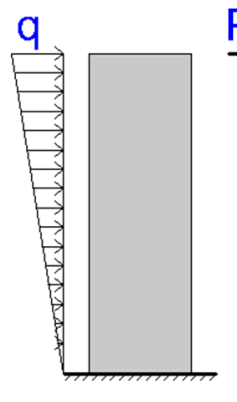

P1

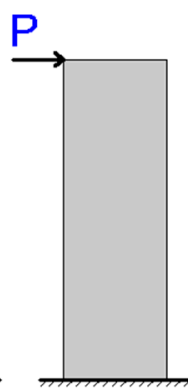

P2

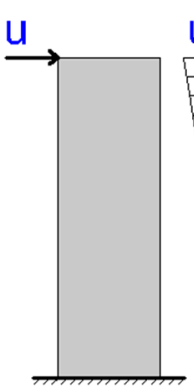

P3

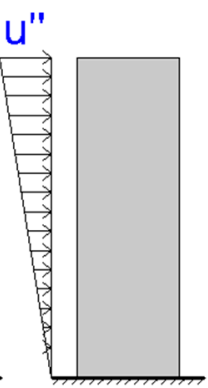

P4

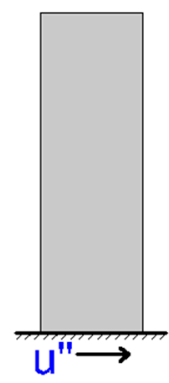

P5

Figure 1. Graphical representation of the considered load patterns.

- P1-inverse triangular shape body forces are applied along the height of the tower.

- $\quad$ P2 - a concentrated lateral load is applied at the top of the tower.

- P3-a lateral displacement is applied at the top of the tower. A constraint is implemented for the top nodes in order to avoid localized damages.

- P4-an inverse triangular shape acceleration is applied along the height of the tower. The acceleration is progressively incremented in a quasi-static fashion. Quasi-static analyses can be conducted in Abaqus for linear or nonlinear problems, and inertial effects can be neglected [41]. The equilibrium formulation of this analysis is given by Equation (1). This approach allows for mimicking any shape for any required load patterns and it is suitable for applying the modal pushover analysis.

$$
M \ddot{x}+C \dot{x}+K x=-M r \ddot{u}
$$

- P5-a progressively incremental acceleration is applied at the base of the tower. The base is not fixed, and the imposed inertial forces exhibit the equivalent seismic forces due to wave propagation in the solid. This approach only mimics the nonlinear dynamic simulations in an incremental fashion, without load cycles. The equilibrium formulation of this analysis is given by Equation (2). The implemented loads resemble seismic loads induced by a ground acceleration at the base and, thenceforth, the structural response is a combination of the wave propagation and inertial forces. This approach could not mimic different shapes of load patterns and it is not very stable due to the induced oscillation of the structure.

$$
M \ddot{x}+C \dot{x}+K x=-\left\{\begin{array}{l}
0 \\
\ddot{u}
\end{array}\right\}
$$

$M$-mass matrix, $C$-damping matrix, $K$-stiffness matrix, $x$-displacement vector, $r$-shape vector, and $\ddot{u}$-induced acceleration. The first load pattern (P1) represents the classical distribution of seismic forces, and the conducted analyses are force-controlled. The second (P2) and third (P3) are considered here to show the difference between a force-controlled and displacement-controlled analysis, respectively. The fourth (P4) would represent a classical force distribution implemented with a displacement controlled fashion, and the fifth load pattern (P5) is here for comparison purposes.

\subsection{Pushover Capacity Curve Shape}

As previously mentioned, the seismic assessment, according to a pushover analysis, is influenced by many parameters that, consequently, change the quality of the pushover curve. The following describes notable characteristics of the capacity curves, see Figure 2, 
according to the considered load patterns. The three significative points of the pushover in a capacity curve are the yield point (A), the maximum load-bearing capacity (B), and the maximum allowable displacement (C). In principle, these points should indicate the limit states of the structure, and they could also be empirically defined by code limitations, as mentioned in the beginning of Section 2. The most desired output would be to tackle these points from an obtained pushover capacity curve. However, it does not always occur and, as described in this section, the load pattern plays a substantial role. Numerous analyses have been conducted, as will be detailed in the next section, and an extract of them is reported in Figure 2 just for highlighting the characterizing features for each load pattern.

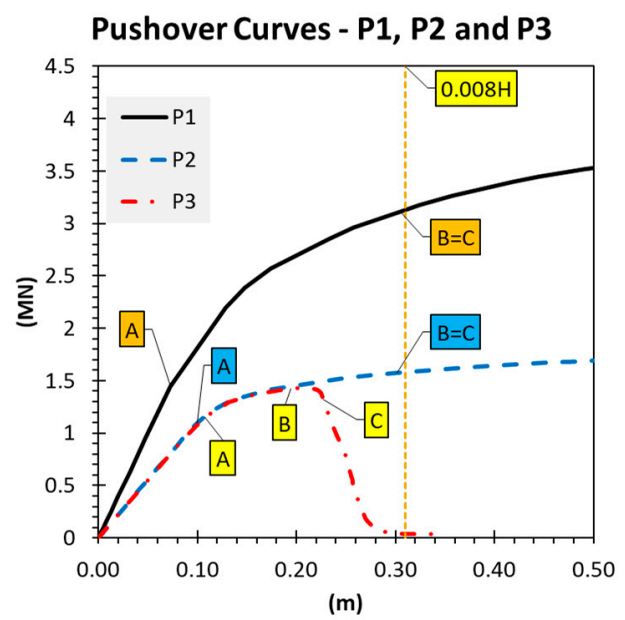

(a)

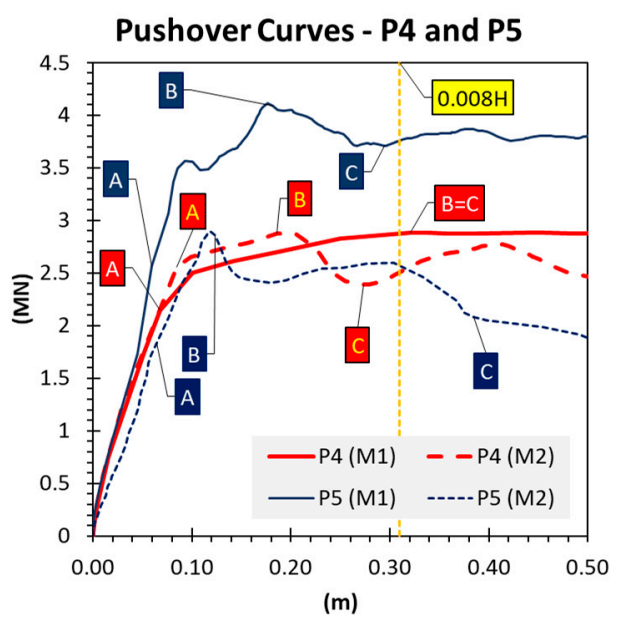

(b)

Figure 2. Characteristics of the pushover curves according to the load pattern; (a) load pattern according to P1, P2 and P3, (b) load pattern according to P4 and P5.

- P1: the base shear of the capacity curve has an increasing trend while the top displacement increases. This is the main drawback of the force-controlled approach, which cannot provide a reliable estimation of structures' maximum load-bearing capacity (point B), as it does not show decreasing values. Consequently, the maximum displacement should be empirically estimated, rather than estimating it from the graph itself.

- $\quad$ By confronting the P2 and P3, see Figure 2a, the pushover curve is identical until the collapse point is identified by the $\mathrm{P} 3$ approach (point $\mathrm{C}$ ). In contrast, the $\mathrm{P} 2$ approach continues to provide a slight increment of the load-bearing capacity, as occurred with P1. These two cases are directly comparable and highlight the benefits and quality of the displacement-control simulations. As can be noted, an empirical estimation might overestimate the maximum allowable top displacement.

- P4: is comparable to the P1 in terms of the globally applied seismic loads; however, this approach incorporates a displacement control by imposing the increment of the applied acceleration. It can be noted that this approach provides all three points. For illustration, Figure $2 \mathrm{~b}$ plots the results from two different materials. The material noted M1 has a perfect elastoplastic behavior while M2 has a multilinear with softening behavior (the details are provided in Section 3.2). The material's role is crucial in providing the ultimate displacement, while, in terms of maximum load-bearing capacity, the presented cases show various similarities. It is worth highlighting that the maximum residual displacement can be empirically estimated between $0.4-0.8 \%$ of the total height, according to [49], or $0.5 \%$ according to code recommendations, [24,50]. For illustration, it is deliberately is chosen that this empirical approach could overestimate the deformation capacity of the towers, see Figure $2 a$ point $C$ of $\mathrm{P} 3$ and Figure $2 b$ point $C$ of $\mathrm{P} 4(\mathrm{M} 2)$. 
- P5: provides a time history nonlinear dynamic curve that is similar to the classic pushover capacity curves. This curve is influenced by the damping parameters and the velocity of the applied load. The initial branch of the capacity curves shows some oscillations due to the tower's elastic dynamic response, as will be shown in the following sections. It can be noted that the initial stiffness of the structure is slightly different from the other cases, due to the nature of the stiffness matrix that is derived from Equation (2). In general, it can be noted that the role of parameters highly influences the shape and quality of the capacity curve. Thenceforth, it is not recommended to be applied massively, but it is worth highlighting that this approach provides critical aspects of the structure's seismic response.

\section{Case Studies}

\subsection{Geometry}

A representative typical masonry tower geometry has been derived from a data bank of selected research papers dealing with seismic assessment and structural health monitoring of masonry towers in the Italian territory [51-62]. Figure 3 summarizes the geometric features of the towers in terms of their slenderness, height, and external base width. A representative tower is chosen for implementing the pushover analysis to address the herein treated issues, i.e., the role of the material, the role of geometry, and load pattern. The chosen tower's basic geometrical properties are: (a) height of $\mathrm{H}=40 \mathrm{~m}$, (b) base $\mathrm{b}=7 \mathrm{~m}$, and (c) a constant wall section thickness of $\mathrm{t}=1.3 \mathrm{~m}$. Among these basic parameters, there are several other parameters, like horizontal elements, openings, belfry, inclination, soil-structure interaction, and adjacent structure interaction, which strongly influence the structure's seismic behavior. This study does not cover all of these parameters. Many of them are out of the scope of this study for providing a practical framework for the implementation of pushover analysis on an accuracy basis. Some of the above-mentioned key features to take under consideration are concluded in three case studies. The three towers have been conceived, as follows, see Figure 4. Tower 1 represents a hollow structure with the given described geometry as above. This approach conforms with the geometry used for the simplified analysis of masonry towers, as described in the guidelines for cultural heritage assessment and preservation under seismic actions [9]. Tower 2 includes some openings along with the height of the tower and vaults according to a typical construction of masonry towers. This model does not consider other typical horizontal timber elements. The belfry zone is composed of pillars and arches representing the cross section's lower rigidity, which often results in the most vulnerable part of the tower accumulating seismic damages. Tower 3 is similar to Tower 2, except for the given inclination that in this study is considered to be equal to $2^{\circ}$.

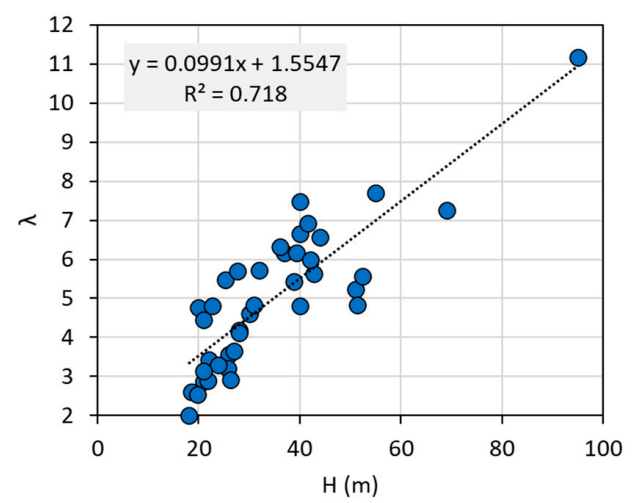

(a)

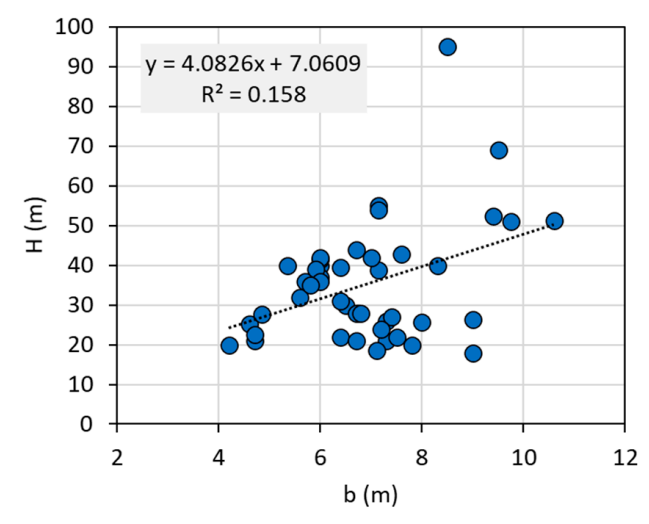

(b)

Figure 3. Correlation of geometrical properties ( $\mathrm{H}$-height; $b$-base width; $\lambda$ —slenderness) from different masonry towers in the Italian territory from literature, (a) the correlation between the height of the structure and slenderness, (b) the correlation between the base width and the tower's height. 
Tower 1

Shaft's cross-section

Shaft's cross-section

Tower 2 and 3

Belfry's cross-Section

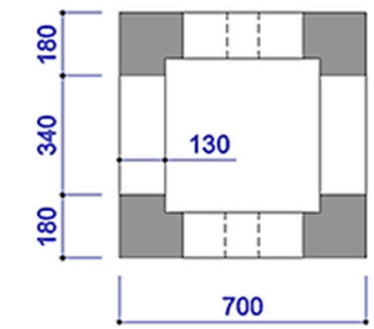

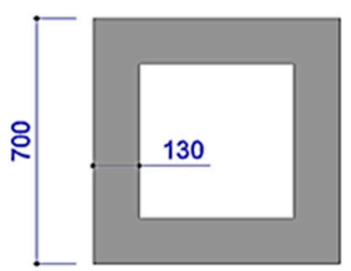

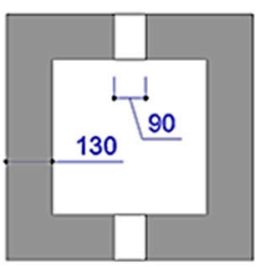

700

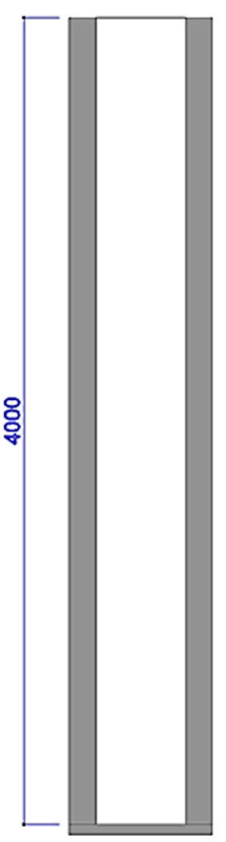

Tower 1
140

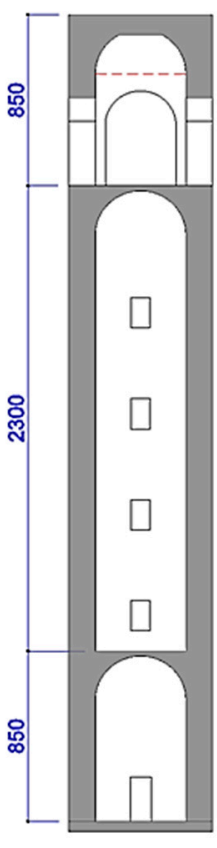

Tower 2

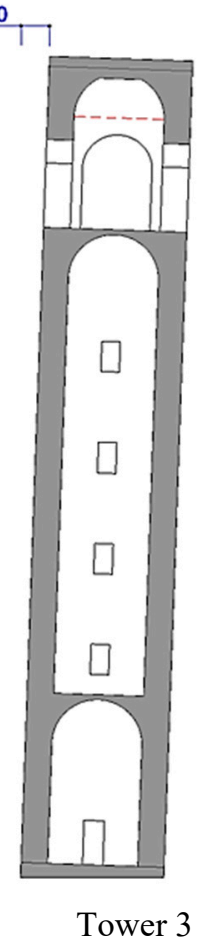

Figure 4. Cross-sections and section views of the towers.

\subsection{Material}

This study considers three different stress-strain relationships of the masonry constitutive law, as shown in Figure 5. Herein, they are denoted: M1-an elasto-plastic material; M2 - brittle material with softening and residual compressive strength; M3-same as material M2, but with a sharper softening branch. The aim of considering different material constitutive laws is to investigate the role of the material properties in the response of masonry towers under nonlinear static simulations.

M1

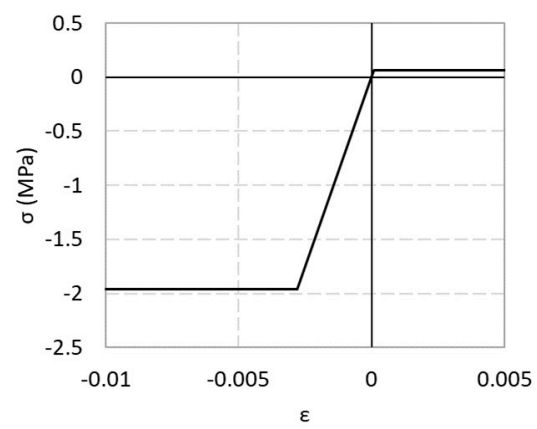

M2

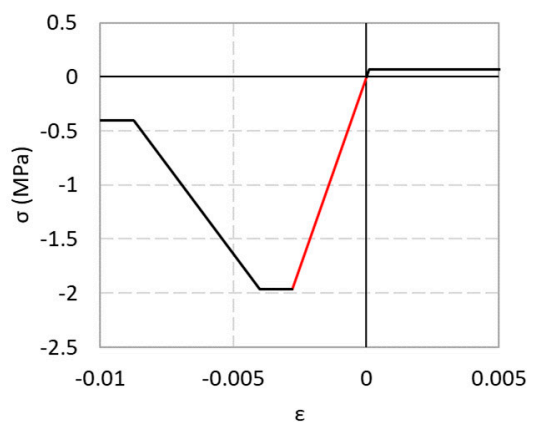

M3

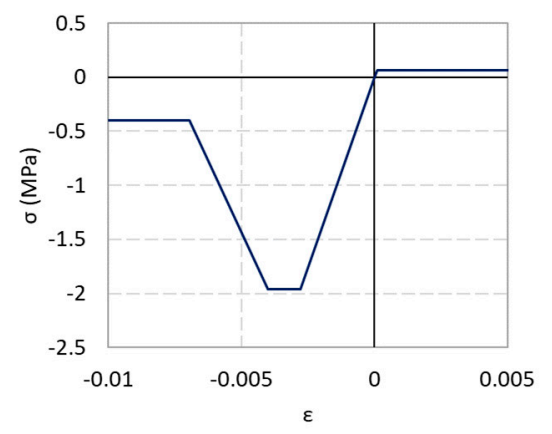

Figure 5. Stress-strain relationship of the masonry, M1-Perfectly elasto-plastic, M2-Idealized brittle material with softening, M3-Idealized brittle material with sudden softening.

A key feature of an accurate pushover curve is the softening branch, after the peak capacity, which is ruled by the softening of the compound material, i.e., the softening branch of the masonry for compressive stresses, as mentioned in the previous section. An elastoplastic material (M1) is often used for modeling masonry structures just to facilitate the numerical convergence of the simulations. It is a convenient approach to reduce the simulation time burdening, and the behavior of the material is similar to the no-tension material model. The last approach is widely used for fast and simplified 
estimation of the masonry element ultimate resistance by means of limit analysis. As expected, the most accurate simulation will be obtained from models, like M2 and M3, as the material tends to more realistically represent stress-strain relationships. However, more brittle that the softening branch is will result in time-consuming and more convergence issues. The reference values of the mechanical properties used for the analysis are taken from Table C8A.2.1 and Table C8A.2.2 of [44]. A minimum level of knowledge (LC1) is considered in this study, which corresponds to a confidence factor FC $=1.35$ that is applied to the compressive strength, tensile strength, and shear strength. A typical masonry material compound of clay bricks and lime mortar is chosen. The characteristic value of the masonry's elastic modulus is recommended to be taken $\mathrm{E}=1500 \mathrm{MPa}$ in a similar case, and a compressive strength $\mathrm{f}_{\mathrm{cm}}=1.92 \mathrm{MPa}(2.6 / 1.35=1.92 \mathrm{MPa})$.

Three-dimensional finite element models are created in the FEM environment of ABAQUS [41], assuming, for masonry, a Concrete Damage Plasticity (CDP) material model that was proposed by Lubliner [63]. The CDP model in Abaqus is described by isotropic elastoplastic behavior constitutive laws defined by different ultimate stress, damage and softening in tension and compression, and a three-dimensional behavior obeying a DruckerPrager failure criterion assuming a non-associated flow rule. The Lubliner model was later modified by proposing a distinct damage parameter for compression and tension [64], as in the following equations.

$$
\begin{aligned}
& \sigma_{t}=\left(1-d_{t}\right) \times E_{0} \times\left(\varepsilon_{t}-\varepsilon_{t}{ }^{p l}\right) \\
& \sigma_{c}=\left(1-d_{c}\right) \times E_{0} \times\left(\varepsilon_{c}-\varepsilon_{c}^{p l}\right)
\end{aligned}
$$

Table 1 reports the adopted parameters of the CDP material model. Although a CDP approach is conceived for isotropic fragile materials, like concrete, it has been widely shown that its basic constitutive law can also be adapted to masonry. Apart from its convenience for accurately reproducing the structural behavior, this model is also available in many other Finite Element codes.

\begin{tabular}{|c|c|c|c|c|}
\hline Dilatation Angle & Eccentricity & $\begin{array}{l}\text { Strength Ratio } \\
\quad \sigma_{b 0} / \sigma_{c 0}\end{array}$ & $\begin{array}{l}\text { Ratio of Tensile and } \\
\text { Compression Stresses in the } \\
\text { Deviatoric Plane k }\end{array}$ & Viscosity \\
\hline $10^{\circ}$ & 0.1 & 1.16 & $2 / 3$ & 0.0002 \\
\hline
\end{tabular}

Table 1. CDP parameters.

The numerical models are discretized while using tetrahedron elements with a characteristic length that is lower than $30 \mathrm{~cm}$. The C3D4 type of Abaqus elements library is selected, and it suits best for meshing any irregular shape and faster numerical processing.

\section{Results}

The extended results from the conducted analyses are reported in the following appendixes, respectively, all the pushover capacity curves in Appendix A and the damage patterns in Appendix B. This section only summarizes the most relevant and illustrative examples.

\subsection{Role of the Geometry}

The tower's geometry is crucial in obtaining a reliable result on the seismic response of the structure. A comprehensive study on the geometrical aspects' role based on simplified numerical models can be found in this literature, [65], where different failure patterns have been observed. The role of the geometry here is not fully comprehensive due to the limited number of the studied towers. However, it highlights the role of structural features like the presence of openings or horizontal elements. Figure 6 confronts the hollow tower T1 with tower T2, where the last is expected to be more realistic. The reported results correspond to the material M3, but it is remarkably similar to the results of M2. Compare Figure A8 
with Figures A9 and A11 with Figure A12. Initially, a concentration of damage in the zone under compression (tracked by the P4 and P5 load pattern approach) can be observed. This highlights the possibility that the initiation of the collapse mechanism could result from combined compressive and shear stresses, which is not the most intuitive one when dealing with low tensile strength materials. Case P1 highlights the damage that is extensively spread in the tensile zone. Besides the load pattern influence, this overall behavior is also affected by the ratio of the cross-section, the wall thickness, and the slenderness. It is worth noting is that the concentration of the damages is not close to the base, but almost to $1 / 4$ of the height. This effect is also observed in a real case study, San Giorgio Tower in Ferrara (Italy). Because of the geometry and the present inclination of the tower, many conducted nonlinear time history analyses have highlighted the initiation of a failure pattern with a diagonal crack shape in the compressed side located almost closes to the $1 / 4$ of the tower's height [26].

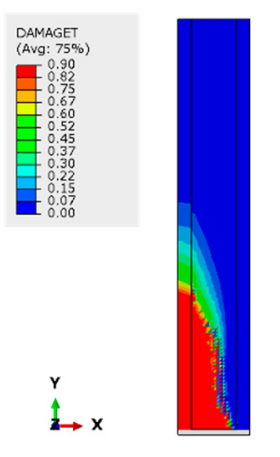

T1-P1

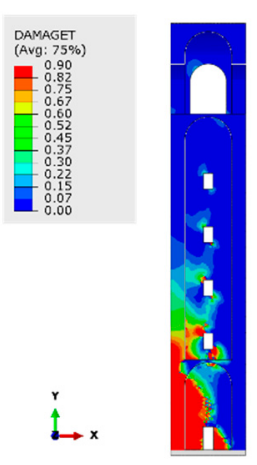

T2-P1

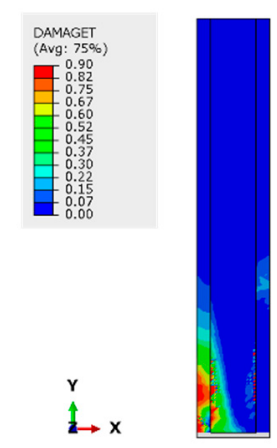

T1-P4-B

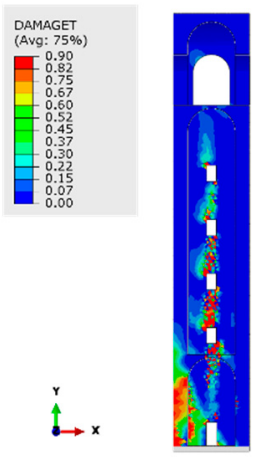

T2-P4-B

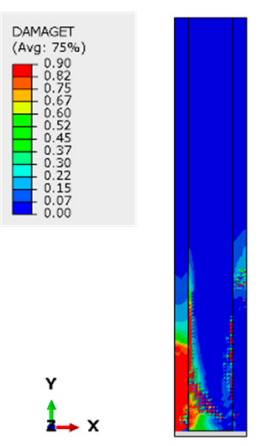

T1-P4-C

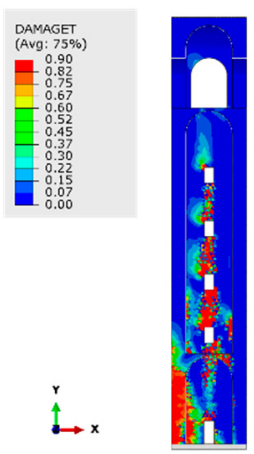

T2-P4-C

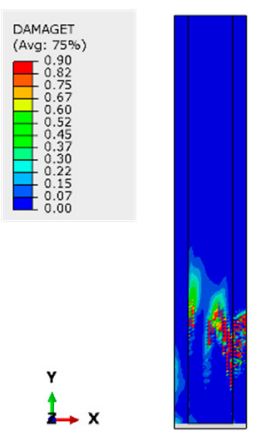

T1-P5-B

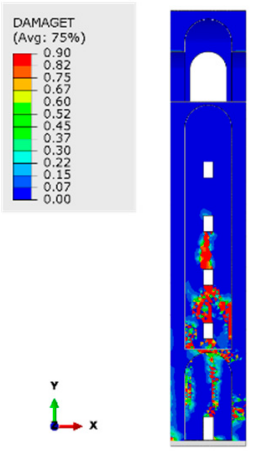

T2-P5-B

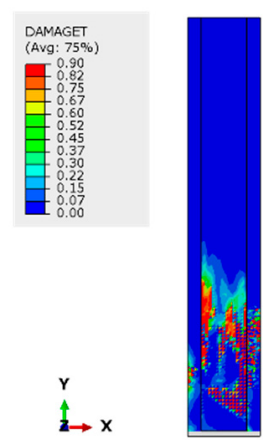

T1-P5-C

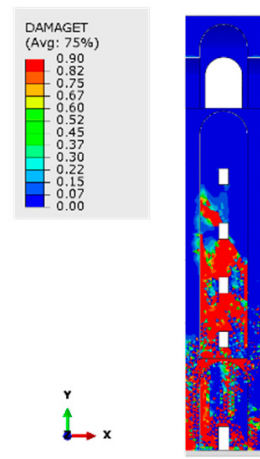

T2-P5-C

Figure 6. Damage pattern comparison between the hollow tower (Tower T1) in the upper images and the "realistic tower" (Tower T2) in the lower images respectively for the points defined in Section 2.2.

The role of the geometry is also represented here by the presence of openings, which is demonstrated by an apparent vertical cracking passing through the openings, see Figure 6 . This result implies the necessity to address a more detailed numerical approach model, where the simplified ones, as proposed in $[9,10]$, could fail to distinguish the most prone active mechanism.

In terms of load-bearing capacity, i.e., the maximum base shear, the present case studies do not indicate a very substantial difference, ranging between 2-2.5 MN. On the other hand, the inclination significantly decreases the load-bearing capacity, which, for the present tower (T3), ranges between 1.4-2.2 MN. An inclination of $2^{\circ}$ is considered to be a high inclination, while considering that the highest registered inclination for masonry towers is approximately $4^{\circ}$. Thenceforth, this reduction of the base shear is justified also 
considering that, for an inclination angle $\alpha \approx \arctan (0.7125 / \lambda)$, the towers lose their stability from the self-weight [66]. However, the most important output is the oscillations from conducting a full nonlinear dynamic analysis (i.e., P5), see Figure 7, Tower 3 case.
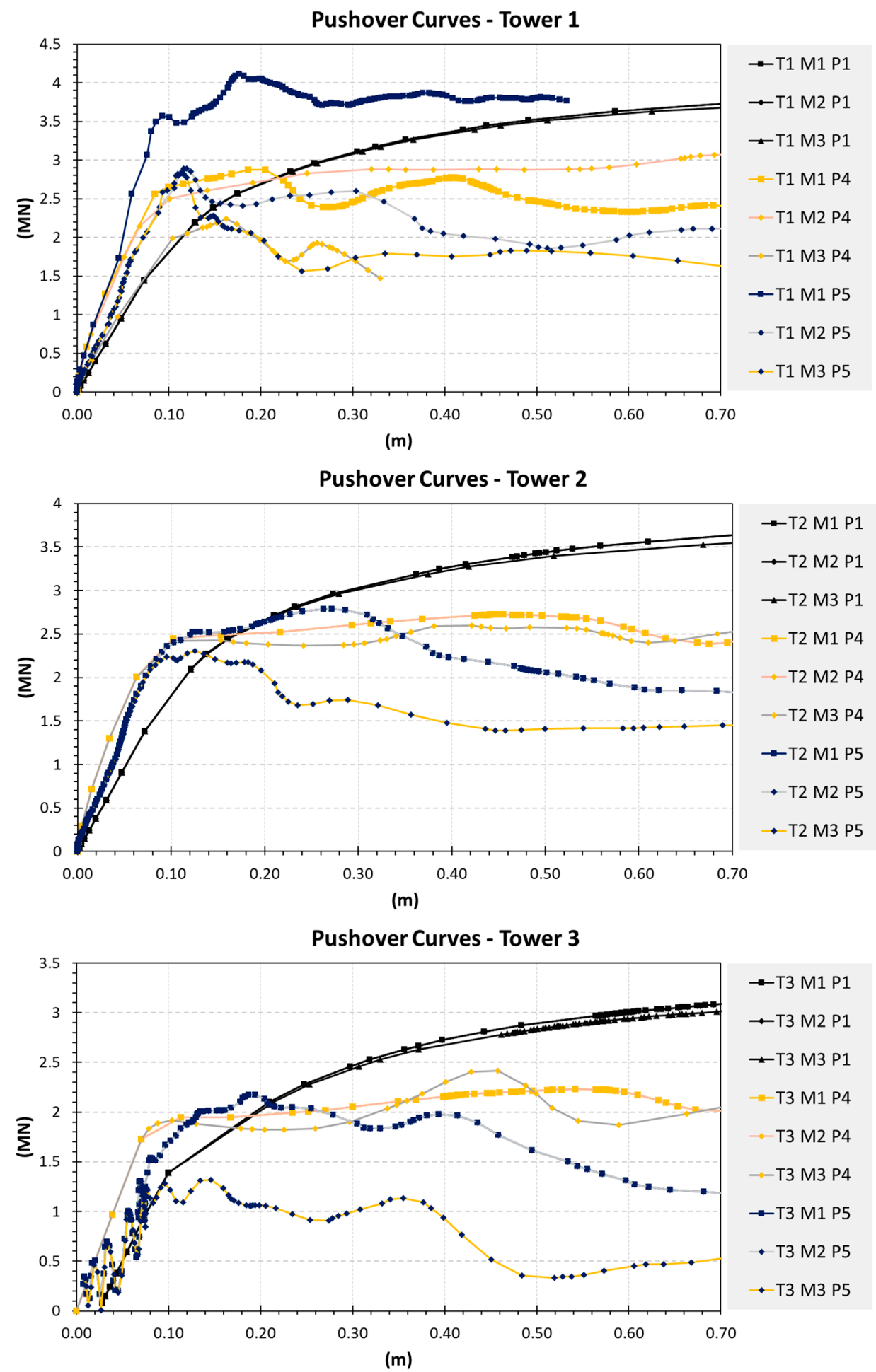

Figure 7. Pushover capacity curves under P1, P4 and P5 load patterns for (top to bottom) Tower 1, Tower 2 and Tower 3 respectively.

As expected, a full nonlinear dynamic will cause oscillations of the structure during the initial steps of the numerical simulation, where it occurs that the structure is in the elastic phase. These observed oscillations in the initial branch, which are clearly distinguishable 
for Tower 3 in see Figure 7, make it difficult to segregate a linear branch representing the elastic phase of the pushover capacity curve. Approaching the pushover analysis according to the herein considered P5 load pattern is not always reliable for obtaining pushover capacity curves, as mentioned in the previous paragraph.

\subsection{Role of Damping}

The following results are referred to as the P5 load pattern alone, as the other approaches are strictly static where the role of damping is completely eliminated. Applying a full dynamic simulation for mimicking a pushover analysis will result in an oscillation behavior, as mentioned in the previous section. Two approaches can be followed for decreasing this effect: (i) modifying the damping properties of the material and (ii) applying a quasi-static analysis approach [41]. Figure 8 shows the results from the first approach. It can be observed that, by increasing the material damping, the oscillation is faded proportionally. However, the most significant disadvantage is that this approach falsely increases the load resisting capacity. The resultant pushover curve becomes alike with a simulation of force-controlled or with elasto-plastic materials where the softening branch is missing.
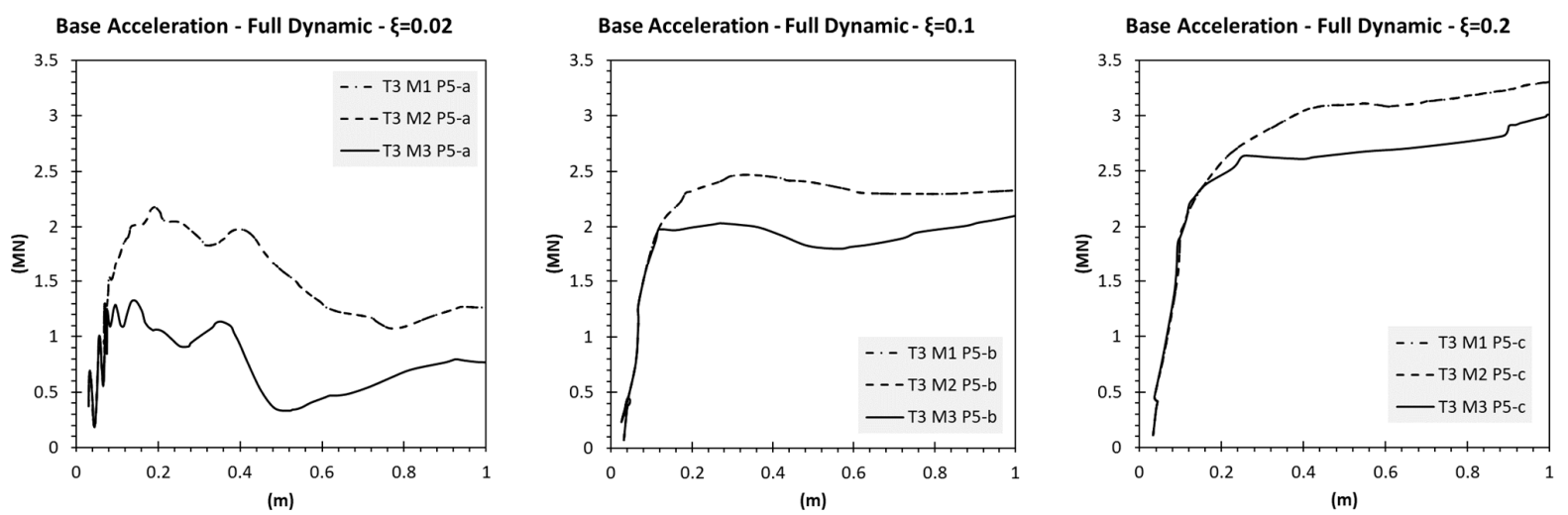

Figure 8. Role of damping in the pseudo-static pushover curves, from left to right the damping ratio increases from $0.02,0.1$ and 0.2 .

Figure 9 shows the results of the second approach. A spike is observed on the pushover capacity curve, which exceeds any estimation of the base shear load-bearing capacity. The same trend as in the first approach is registered while increasing the damping coefficient. It is worth noting that, for relatively elevated values of damping, the obtained pushover curves from both approaches are similar, and the overall estimated maximum base shear is comparable, even with the results from P1 and P4 load patterns.
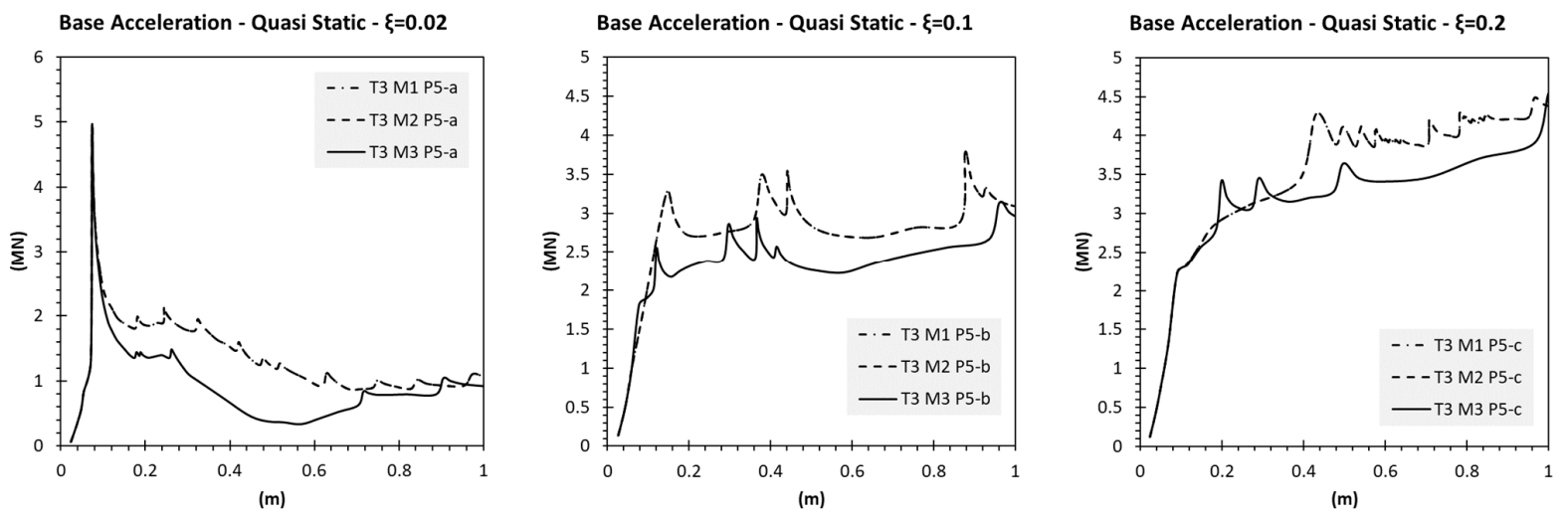

Figure 9. Role of damping in the quasi-static pushover curves, from left to right the damping ratio increases from $0.02,0.1$ and 0.2 . 


\subsection{Role of Material}

Regarding the material properties, the role of the tensile strength is not investigated here, but it is acknowledged as a parameter that strongly influences the load-bearing capacity. The compressive strength here is exposed to control both the bearing capacity and the damage pattern, as discussed in Section 4.1. A comparable response is registered for the M1 (elasto-plastic) and the M2 (elasto-plastic with softening) in terms of the capacity curve and damage pattern, refer to Appendices A and B, respectively. For a force-controlled pushover, the differences are negligible. Hence, if the nonlinear static analysis is implemented based on a force-controlled approach (in the absence of implementing a displacement-controlled due to a software constrain), the stress-strain relationship shape might be transcurred. Instead, the focus should be on other ruling parameters. The difference between an M2 and M3 type is quite visible for displacement-controlled alike approaches, see Figure 7. Thenceforth, defining the softening branch will strongly influence the point of structural collapse (maximum displacement acceptable for the structure) and, consequently, affects the reliability of the simulations.

The role of the material is notable for the P5 approach, where a small variation causes big changes in the global response. For a load pattern, like the P4 approach, the softening branch is not always very notable, as the quasi-static analysis tends to modify the overall stiffness and hinder the inertial effect. It will bring out similarities with the role of damping, as in Figures 8 and 9. In this case, it is suggested to investigate the softening branch carefully in order to obtain the maximum displacement accompanied by a decreasing base shear.

\subsection{Role of Load Pattern}

The most reliable and practical load pattern is the P4, where an incremental acceleration is applied along the height of the tower (structure) according to a preassigned distribution shape, as highlighted in the previous comments and sections. This loading pattern seems to provide a sharp shape when the geometry is very simple; however, it worth noting that other cases should be paid more attention. The observed effect of an increment of the base shear after the capacity curves demonstrate a softening branch is partially influenced by non-considering geometrical nonlinearity and partially by a quasi-static fashion simulation. The geometrical nonlinearity is not considered here for simplicity and even because many types of software do not provide this feature. It would be considered to be acceptable to consider the collapse of the tower, the end of the capacity curve. However, an increment of the base shear is noted to occur after the softening branch for a quite large deformation. This represents a nonphysical phenomenon. This approach is worthy of being compared, for the sake of accuracy, with limitations of the maximum displacements or by adjunct simulations, like P5. The drawbacks that are mentioned above should be addressed, considered, and, if possible, might be eliminated. An alternative is the P3, but it should be paid attention if imposed displacement constraints do not hinder the propagation of failure mechanisms. The last can be illustrated by a concentration of the damages at the belfry, see Figure 10, which is imposed by the local drift at the top and not by the role of higher modes as it is expected in slender structures. 


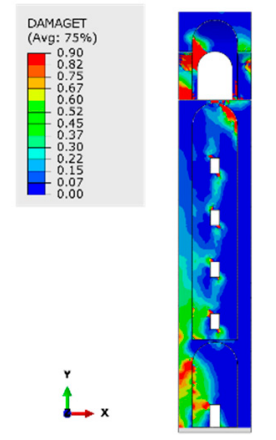

T2-P2-M1

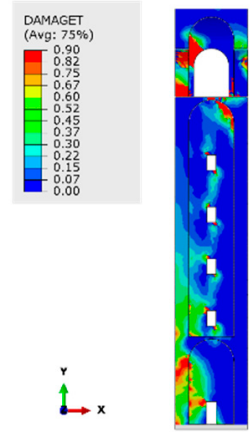

T2-P2-M2

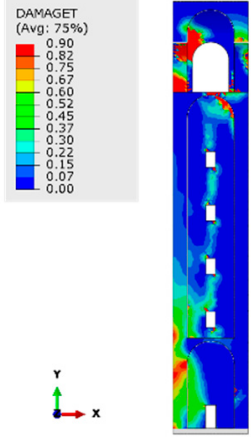

T2-P2-M3

Figure 10. Damage patterns of tower T2 subjected to a displacement at the top, i.e., the load pattern $\mathrm{P} 2$ for three different materials, from left to right $\mathrm{MI}$ to $\mathrm{M} 2$ and M3 respectively.

\section{Discussion}

This research paper is conceived to provide some practical recommendations for the implementation of the pushover analysis. The traditional pushover analysis was initially conceived as nonlinear static procedures where force targets were assigned in the structure. By gradually incrementing the intensity of the force, the algorithm would provide the function of base shear versus the assigned control node's displacement. This approach is valid for definitive loads that are fully known. However, the seismic loads are of inertial nature and they depend on the response of the structure. Any assumption of the seismic loads' distribution in the structure would be only an approximation or at least the one that would bring the structure to a certain limit state. The most accurate assumption would be to apply accelerations with a spatial distribution mimicking the eigenmodes, and this acceleration would be incremented gradually. For practical purposes, by using an advanced FE software package, the best-recommended approach would be to conceptualize a nonlinear dynamic analysis with a user-defined shape distribution of the acceleration in a quasi-static fashion. When compared to other methods, this approximation is quite reliable, and it provides the seismic assessment's required information according to a pushover analysis.

A most rigorous and specific application of such an assumption would permit an increase of the acceleration even the capacity of the structures to withstand those actions is exceeded, thence the compounding bodies of the structure would follow a kinematic motion and the numerical simulation would continue. However, such analysis would require a very advanced model, which would count for geometrical nonlinearities and large displacements. Such approaches are not practical, and they exceed the requirements for seismic assessment. However, from a theoretical point of view, their exploration would be beneficial.

\section{Conclusions}

Pushover analysis is one of the most popular analysis for the seismic assessment of existing structures. The evolution of instruments and the advancement in the masonry modeling approaches that are suitable for nonlinear analysis are seen as a very useful tool. Despite the structural regularity, the pushover analysis is still not an easy task. This is not directly related to the complexity of the model itself, but regarding the accuracy of the obtained base shear-displacement capacity curve. The role of the geometry, material properties, load pattern, and type of analysis (force-controlled vs. displacement-controlled) have been raised in this research. Three case studies, three materials, and five load patterns are the object of this study. From the conducted analysis and obtained results, the most noteworthy remarks to be drawn are.

- The most accurate approach for mimicking seismic loads for a pushover analysis is by imposing gradually incremental acceleration. This approach eliminates fixed 
patterns of loads, which constrain the damage distributions. Many software provides the implementation of this approach in a quasi-static fashion.

- If the practitioner or researcher implements a force-based approach, the role of the material is less relevant when compared to other features of the structure.

- The geometry's role, like horizontal diaphragms, openings, and inclination, strongly influences the shape of the damage pattern. Consequently, the seismic capacity is affected.

- The softening in the stress-strain relationship in compression plays a crucial role in estimating the tower's lowest load-bearing capacity (near collapse) and the maximum allowable deformation. It is recommended that the softening branch should be sharper. Otherwise, a smooth softening fades to tackle the realistic failure of the tower.

Funding: This research received no external funding.

Institutional Review Board Statement: Not applicable.

Informed Consent Statement: Not applicable.

Data Availability Statement: The data presented in this study are available on request from the corresponding author.

Conflicts of Interest: The author declares no conflict of interest.

\section{Appendix A}

The following graphs represent the base shear-top displacement capacity curve for different load patterns and materials.

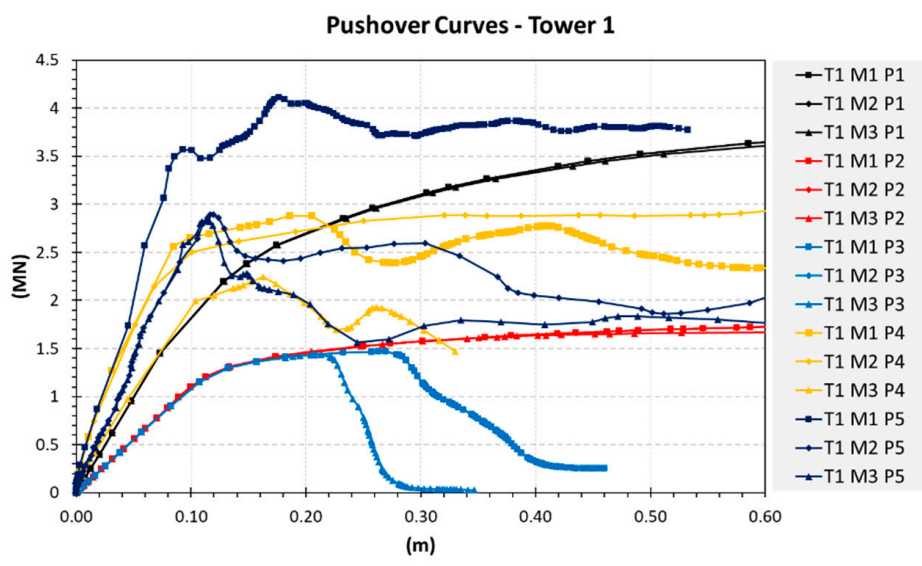

Figure A1. Pushover curves results for the case of Tower 1.

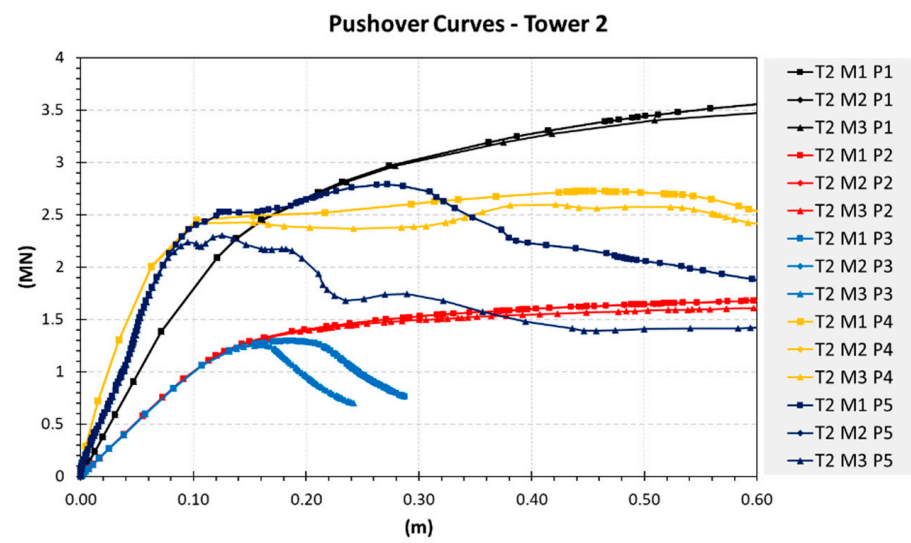

Figure A2. Pushover curves result for the case of Tower 2. 


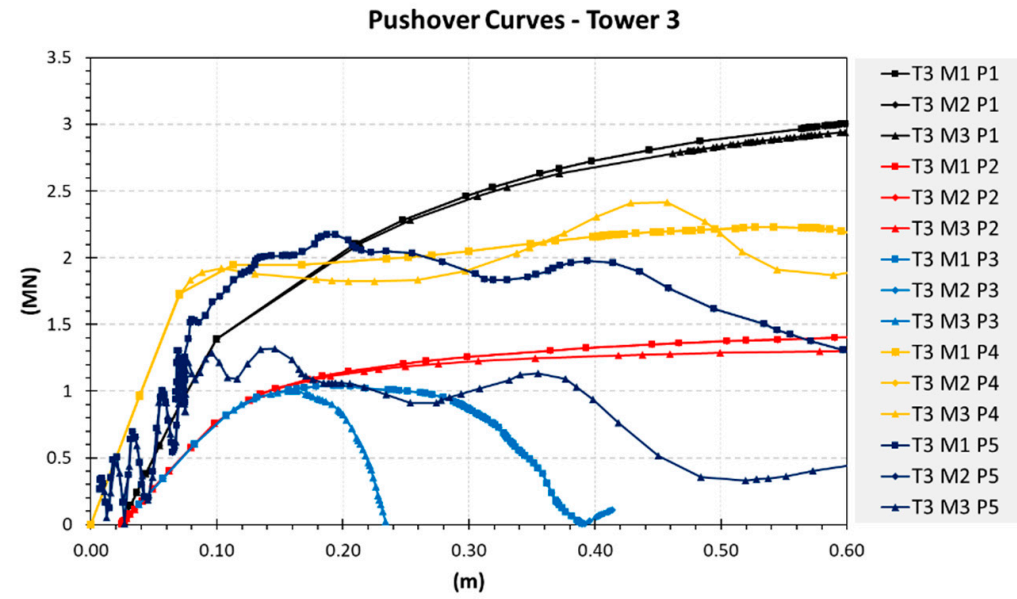

Figure A3. Pushover curves result for the case of Tower 3.

\section{Appendix B}

The following images represent the damage pattern of the towers due to different load patterns and intensity. P1 load pattern damage for ultimate displacement. P2 load pattern damage for ultimate displacement. P2 load pattern damage for ultimate displacement. P3-A load pattern damage for damage initiation point. P3-B load pattern damage for ultimate displacement. P4-A load pattern damage for damage initiation point. P4-B load pattern damage for maximum base shear. P4-C load pattern damage for ultimate displacement. P5-A load pattern damage for damage initiation point. P5-B load pattern damage for maximum base shear. P5-C load pattern damage for ultimate displacement.

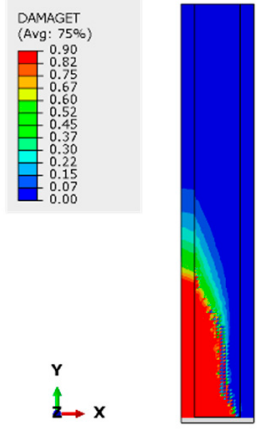

P1

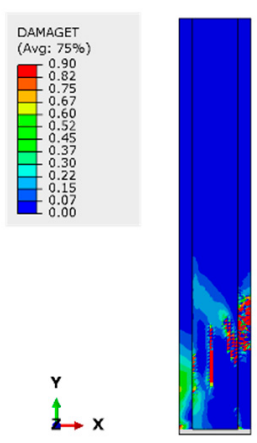

P4-B

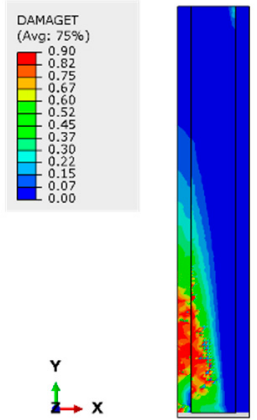

P2

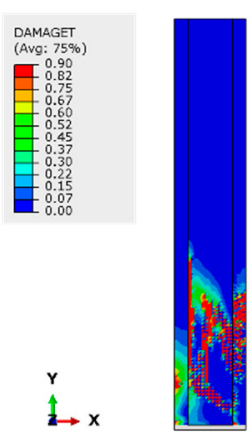

P4-C

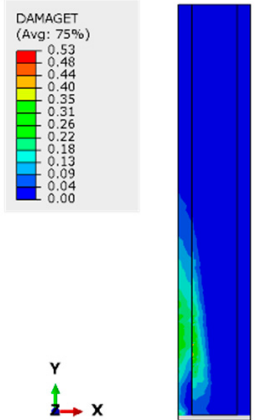

P3-A
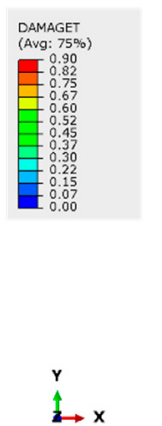

P5-A

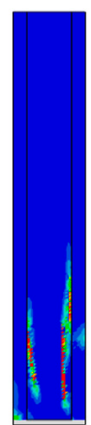

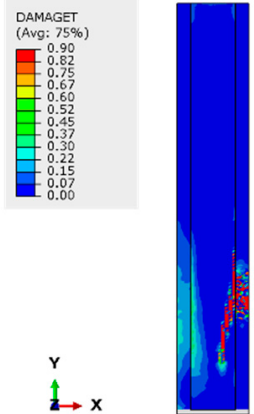

P3-B

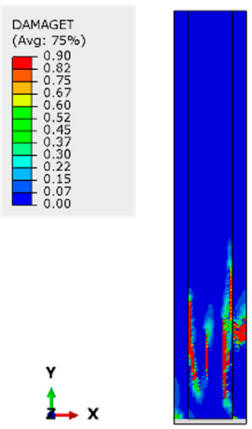

P5-B

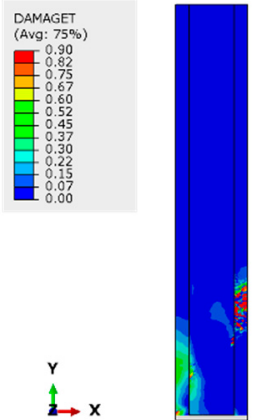

P4-A

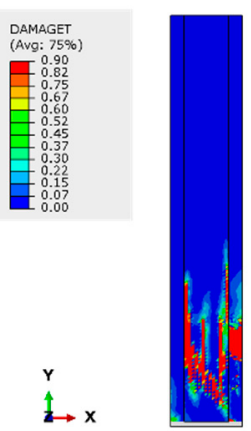

P5-C

Figure A4. Pushover analyses results of T1-M1—Damage patterns. 


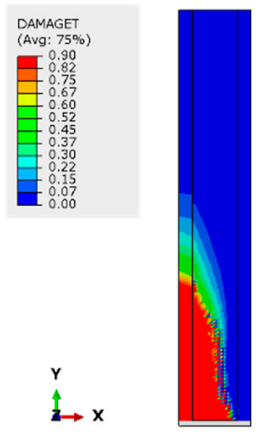

P1

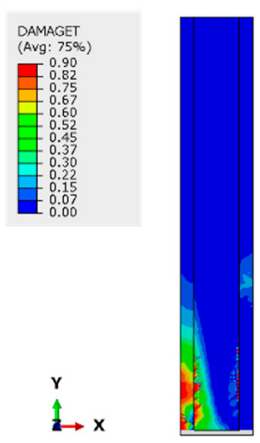

P4-B

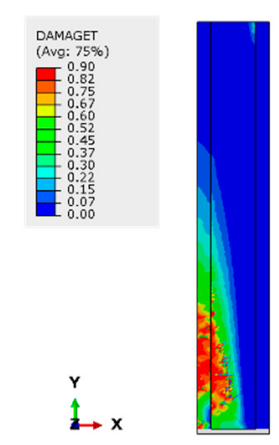

P2

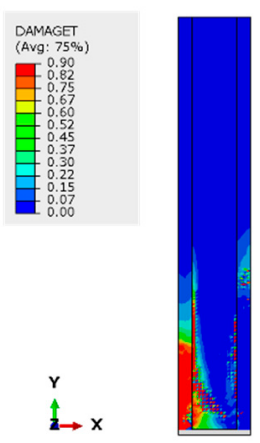

P4-C

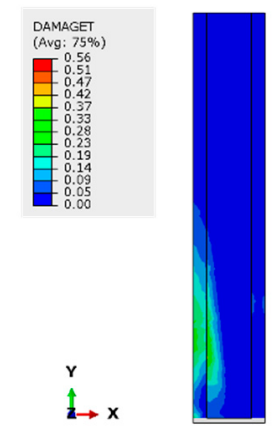

P3-A

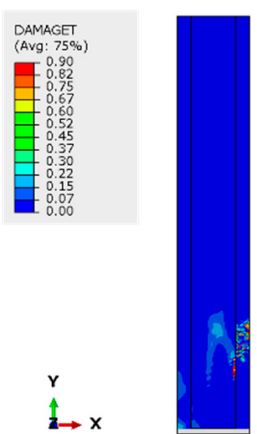

P5-A

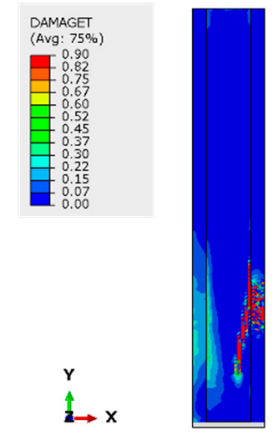

P3-B

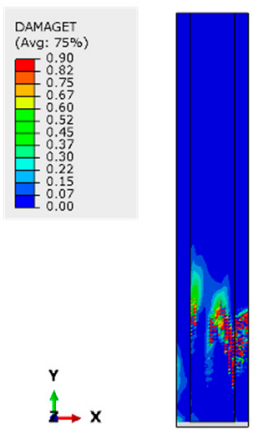

P5-B

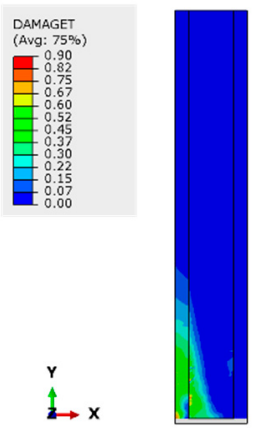

P4-A

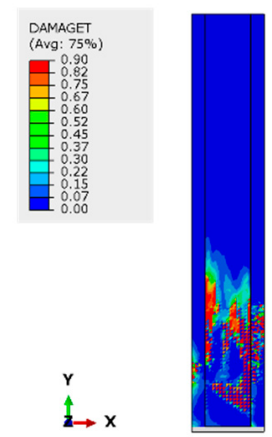

P5-C

Figure A5. Pushover analyses results of T1-M2-Damage patterns.

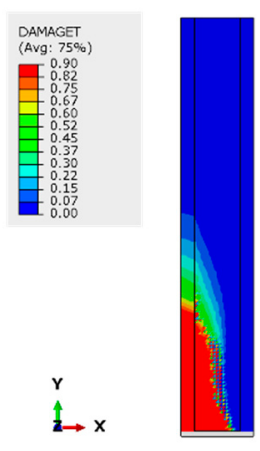

P1

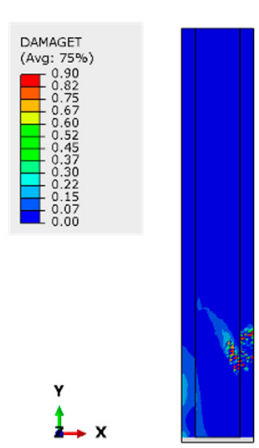

P4-B

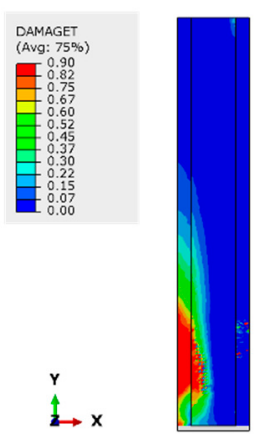

P2

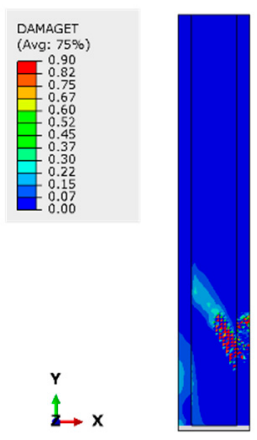

P4-C

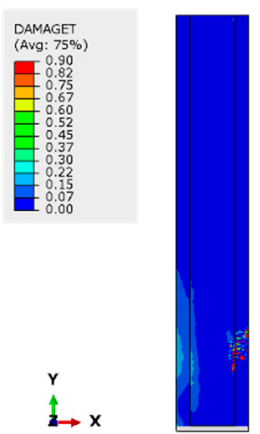

P3-A

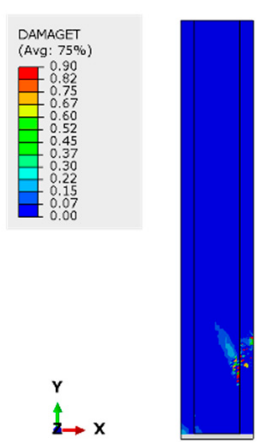

P5-A

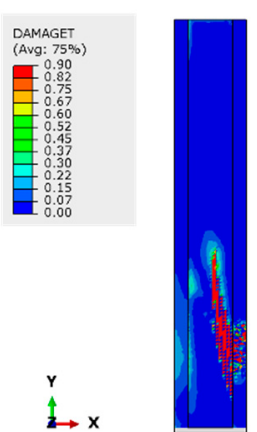

P3-B

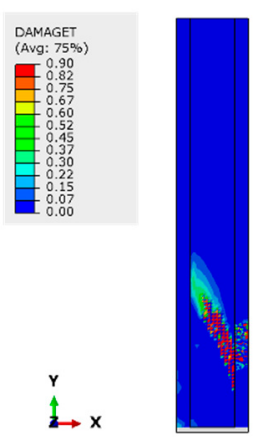

P5-B

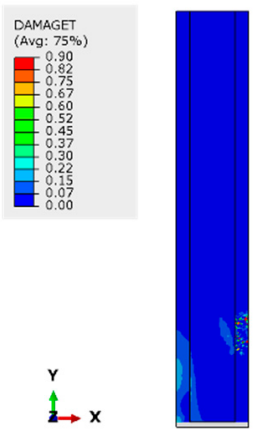

P4-A

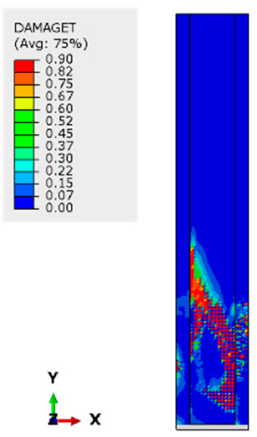

P5-C

Figure A6. Pushover analyses results of T1-M3-Damage patterns. 


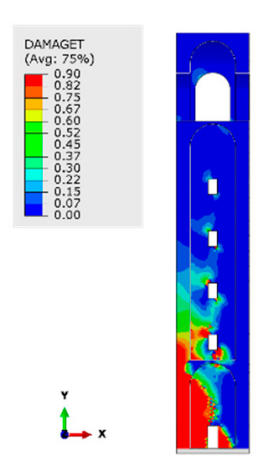

P1

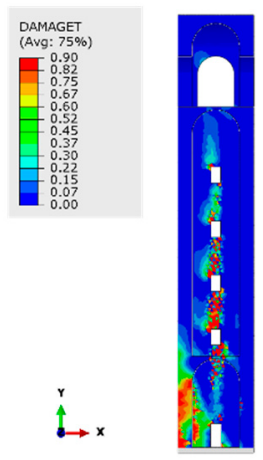

P4-B

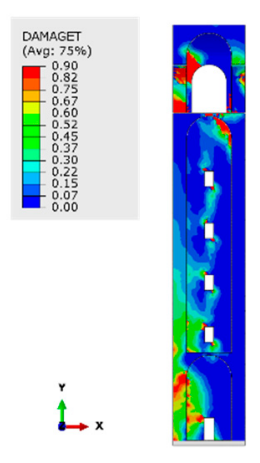

P2

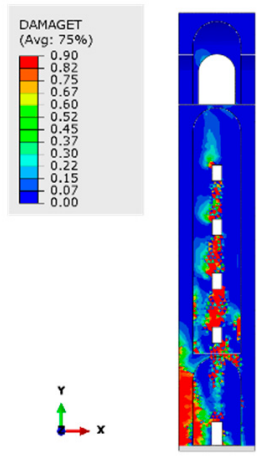

P4-C

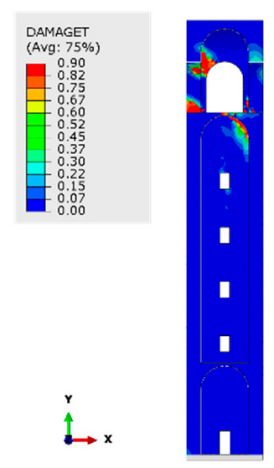

P3-A

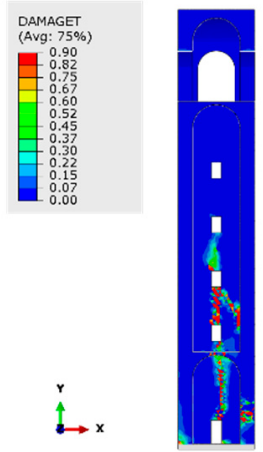

P5-A

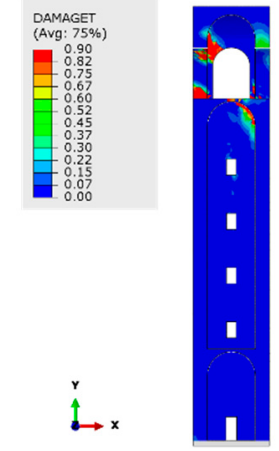

P3-B

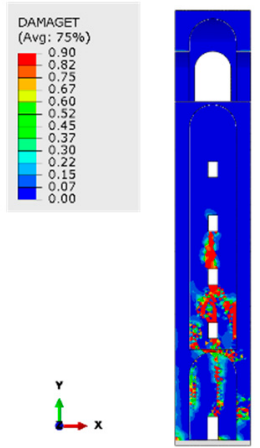

P5-B

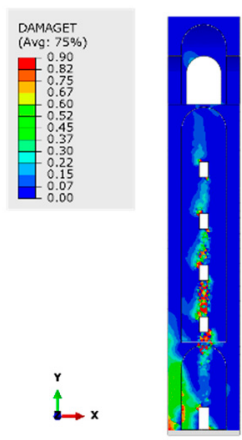

P4-A

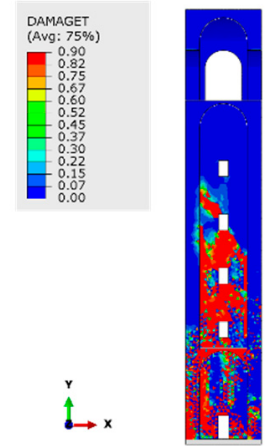

P5-C

Figure A7. Pushover analyses results of T2-M1-Damage patterns.

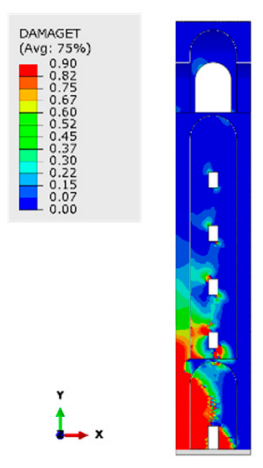

P1

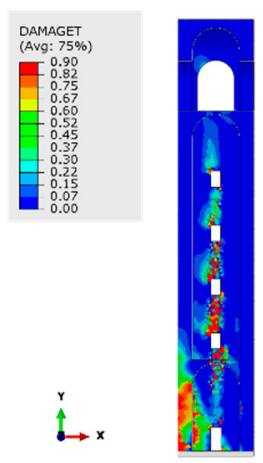

P4-B

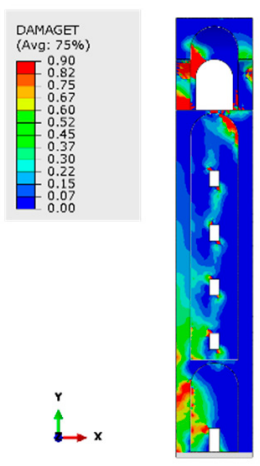

P2

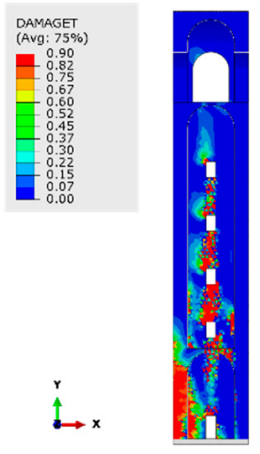

P4-C

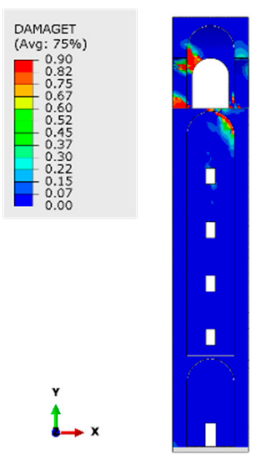

P3-A

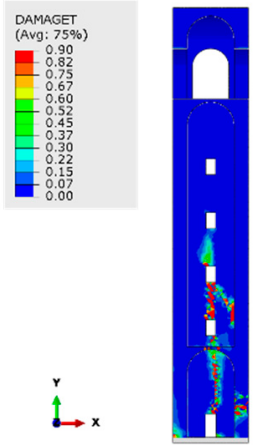

P5-A

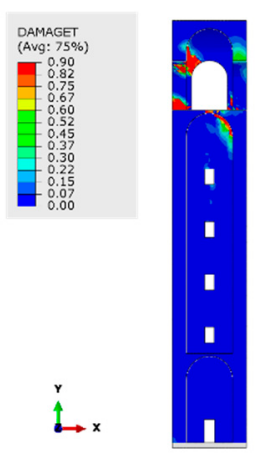

P3-B

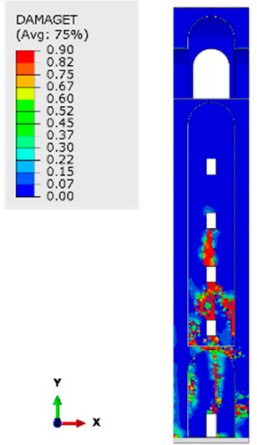

P5-B

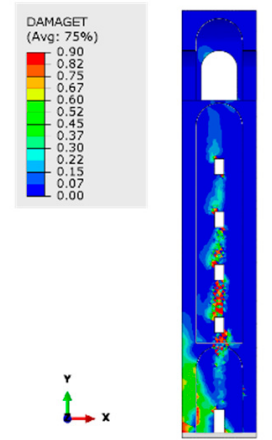

P4-A

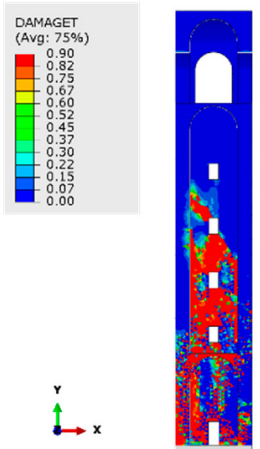

P5-C

Figure A8. Pushover analyses results of T2-M2-Damage patterns. 


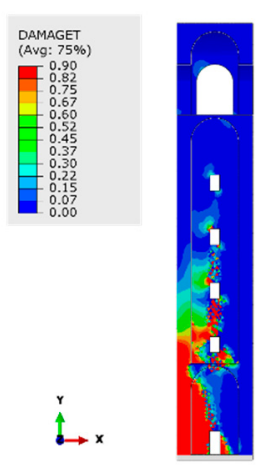

P1

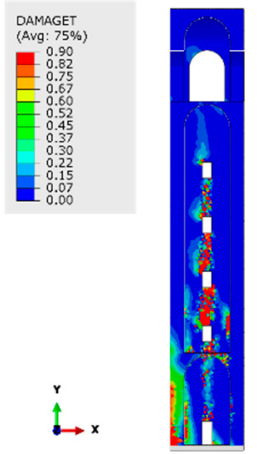

P4-B

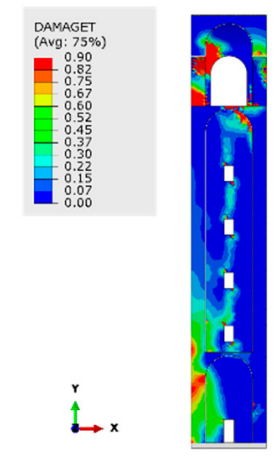

P2

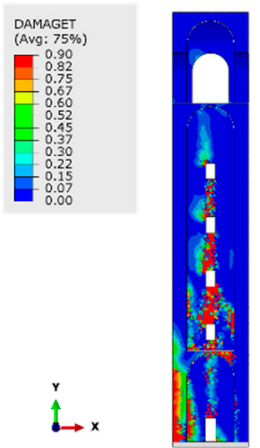

P4-C

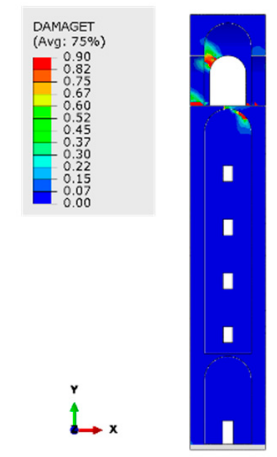

P3-A

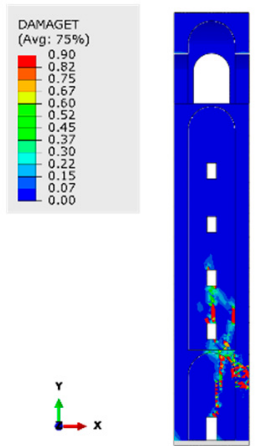

P5-A

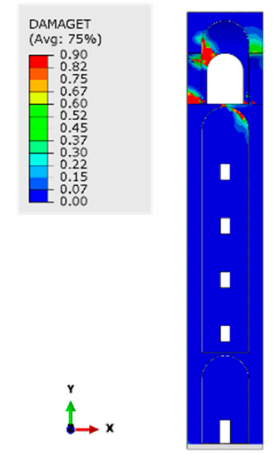

P3-B

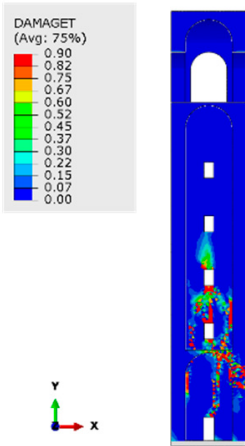

P5-B

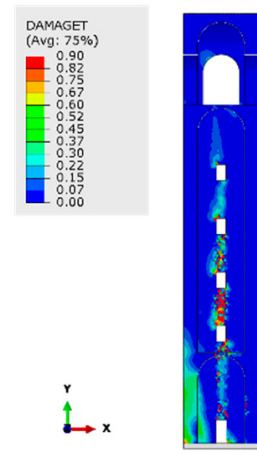

P4-A

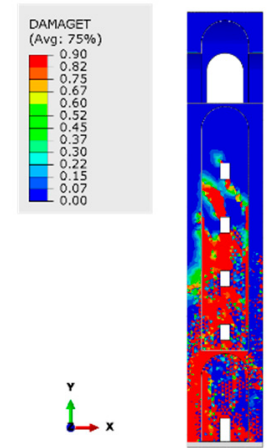

P5-C

Figure A9. Pushover analyses results of T2-M3-Damage patterns.

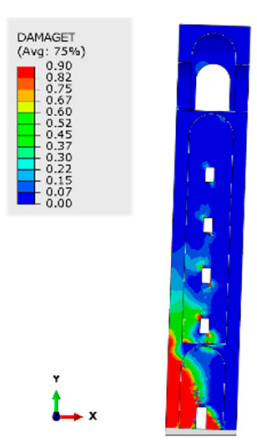

P1

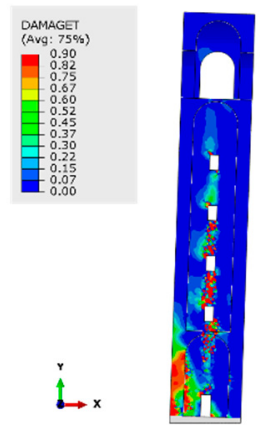

P4-B

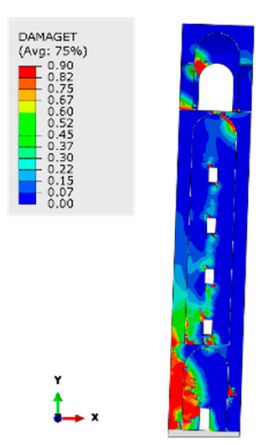

P2

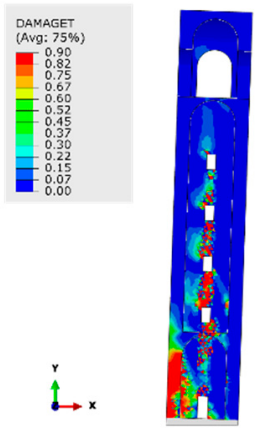

P4-C

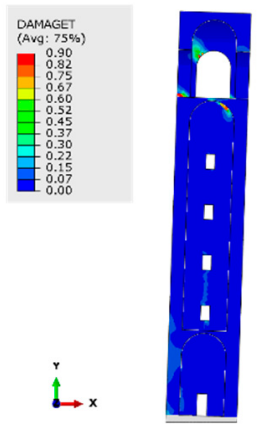

P3-A

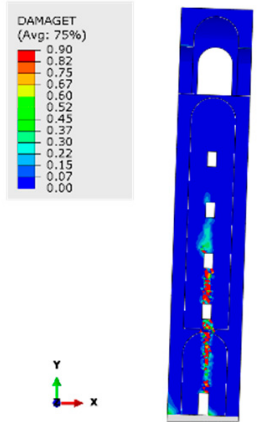

P5-A

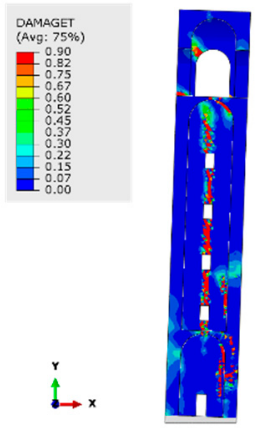

P3-B

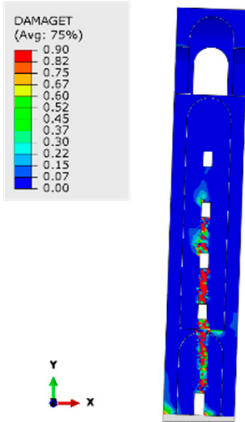

P5-B

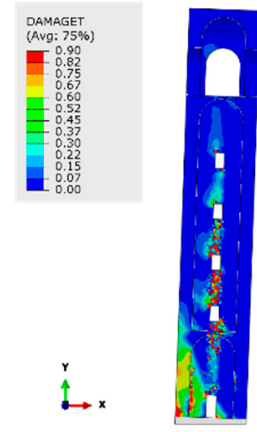

P4-A

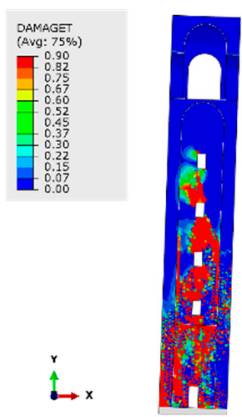

P5-C

Figure A10. Pushover analyses results of T3-M1-Damage patterns. 


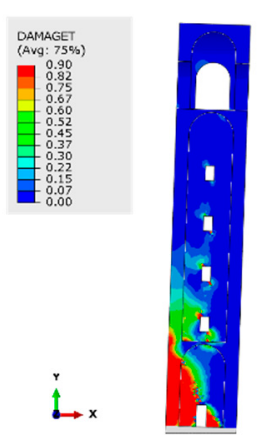

P1

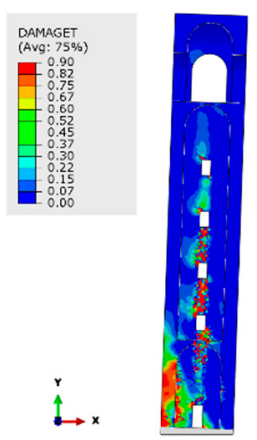

P4-B

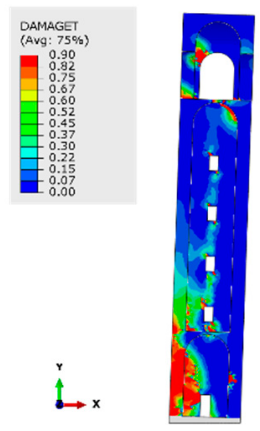

P2

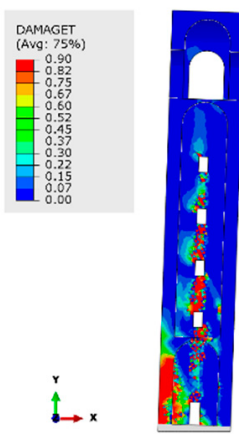

P4-C

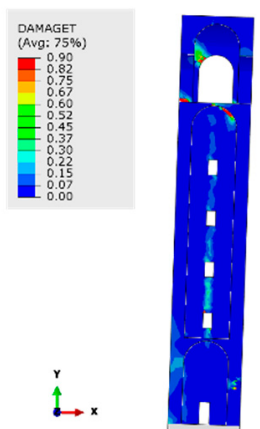

P3-A

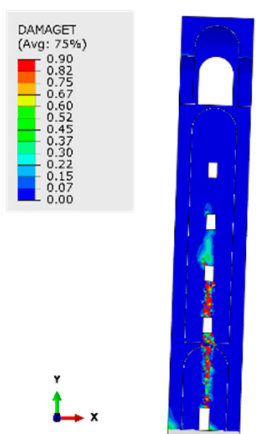

P5-A

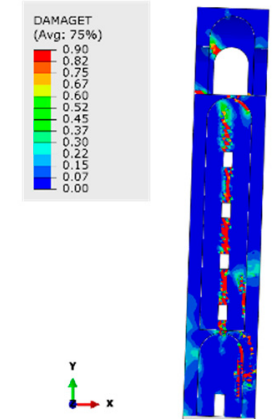

P3-B

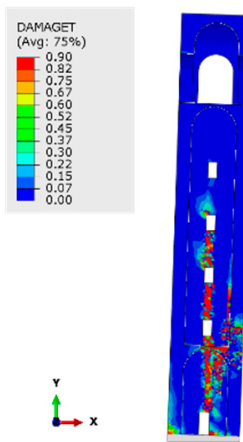

P5-B

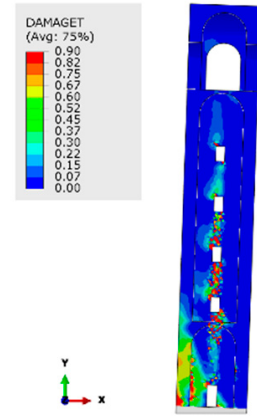

P4-A

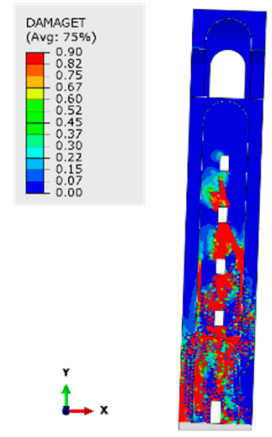

P5-C

Figure A11. Pushover analyses results of T3-M2-Damage patterns.

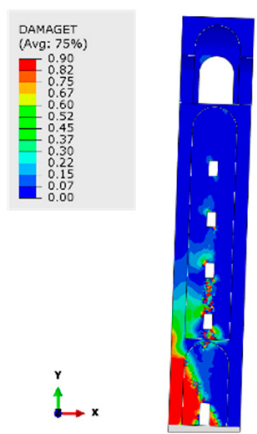

P1

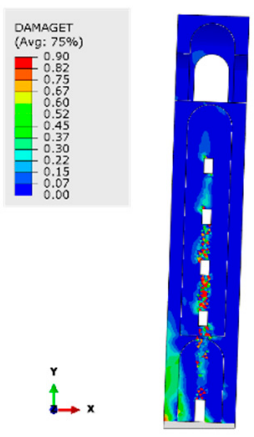

P4-B

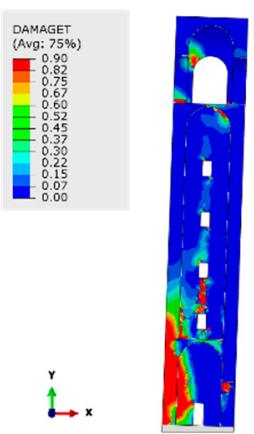

P2

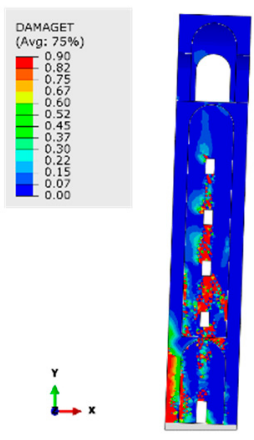

P4-C

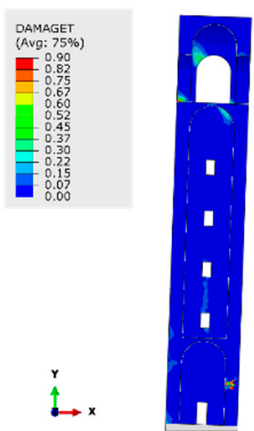

P3-A

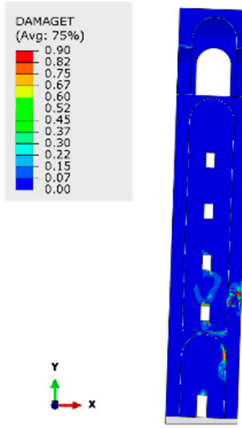

P5-A

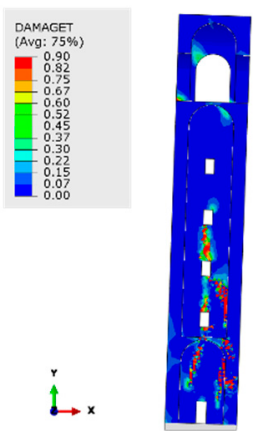

P3-B

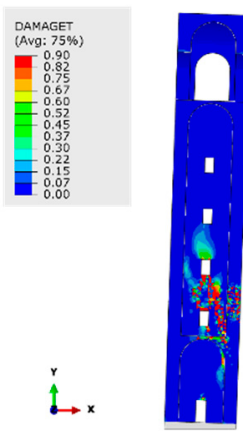

P5-B

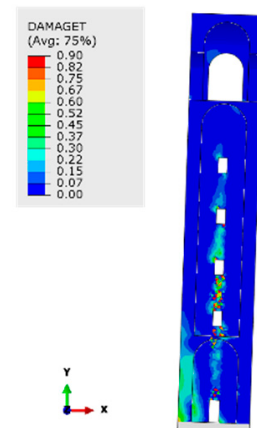

P4-A

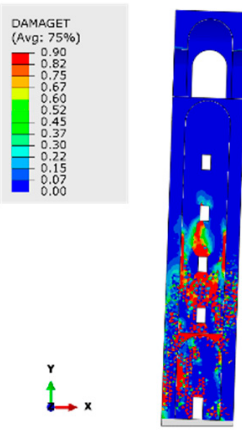

P5-C

Figure A12. Pushover analyses results of T3-M3-Damage patterns. 


\section{References}

1. Asteris, P.G.; Moropoulou, A.; Skentou, A.D.; Apostolopoulou, M.; Mohebkhah, A.; Cavaleri, L.; Rodrigues, H.; Varum, H. Stochastic vulnerability assessment of masonry structures: Concepts, modeling and restoration aspects. Appl. Sci. 2019, 9, 243. [CrossRef]

2. Clementi, F.; Gazzani, V.; Poiani, M.; Lenci, S. Assessment of seismic behaviour of heritage masonry buildings using numerical modelling. J. Build. Eng. 2016, 8, 29-47. [CrossRef]

3. Ciocci, M.P.; Sharma, S.; Lourenço, P.B. Engineering simulations of a super-complex cultural heritage building: Ica Cathedral in Peru. Meccanica 2018, 53. [CrossRef]

4. Rossi, E.; Grande, F.; Faggella, M.; Tarque, N.; Scaletti, A.; Gigliotti, R. Seismic Assessment of the Lima Cathedral Bell Towers via Kinematic and Nonlinear Static Pushover Analyses. Int. J. Archit. Herit. 2020. [CrossRef]

5. Preciado, A.; Sperbeck, S.T.; Ramirez-Gaytan, A. Seismic vulnerability enhancement of medieval and masonry bell towers externally prestressed with unbonded smart tendons. Eng. Struct. 2016, 122, 50-61. [CrossRef]

6. Bocciarelli, M.; Barbieri, G. A numerical procedure for the pushover analysis of masonry towers. Soil Dyn. Earthq. Eng. 2017, 87. [CrossRef]

7. Peña, F.; Lourenço, P.B.; Mendes, N.; Oliveira, D.V. Numerical models for the seismic assessment of an old masonry tower. Eng. Struct. 2010, 32, 1466-1478. [CrossRef]

8. Zanotti Fragonara, L.; Boscato, G.; Ceravolo, R.; Russo, S.; Ientile, S.; Pecorelli, M.L.; Quattrone, A. Dynamic investigation on the Mirandola bell tower in post-earthquake scenarios. Bull. Earthq. Eng. 2017, 15, 313-337. [CrossRef]

9. Preciado, A.; Bartoli, G.; Ramírez-Gaytán, A. Earthquake protection of the Torre Grossa medieval tower of San Gimignano, Italy by vertical external prestressing. Eng. Fail. Anal. 2017. [CrossRef]

10. Torelli, G.; D'Ayala, D.; Betti, M.; Bartoli, G. Analytical and numerical seismic assessment of heritage masonry towers. Bull. Earthq. Eng. 2020, 18, 969-1008. [CrossRef]

11. Ivorra, S.; Pallarés, F.J.; Adam, J.M. Masonry bell towers: Dynamic considerations. Proc. ICE Struct. Build. 2011, 164, 3-12. [CrossRef]

12. Ferretti, D.; Bažant, Z.P. Stability of ancient masonry towers: Moisture diffusion, carbonation and size effect. Cem. Concr. Res. 2006, 36, 1379-1388. [CrossRef]

13. Bru, D.; Reynau, R.; Baeza, F.J.; Ivorra, S. Structural damage evaluation of industrial masonry chimneys. Mater. Struct. Constr. 2018, 51, 1-16. [CrossRef]

14. López-Patiño, G.; Adam, J.M.; Verdejo Gimeno, P.; Milani, G. Causes of damage to industrial brick masonry chimneys. Eng. Fail. Anal. 2017, 74, 188-201. [CrossRef]

15. Chieffo, N.; Clementi, F.; Formisano, A.; Lenci, S. Comparative fragility methods for seismic assessment of masonry buildings located in Muccia (Italy). J. Build. Eng. 2019, 25. [CrossRef]

16. Makris, N.; Alexakis, H. Limit equilibrium analysis of masonry buttresses and towers under lateral and gravity loads. Arch. Appl. Mech. 2015, 85, 1915-1940. [CrossRef]

17. DPCM. Linee guida per la valutazione e la riduzione del rischio sismico del patrimonio culturale con riferimento alle Norme tecniche per le costruzioni di cui al decreto del M.I.T del (2008); Italy, 2011.

18. Bartoli, G.; Betti, M.; Monchetti, S. Seismic Risk Assessment of Historic Masonry Towers: Comparison of Four Case Studies. J. Perform. Constr. Facil. 2017, 31, 04017039. [CrossRef]

19. Asteris, P.G.; Chronopoulos, M.P.; Chrysostomou, C.Z.; Varum, H.; Plevris, V.; Kyriakides, N.; Silva, V. Seismic vulnerability assessment of historical masonry structural systems. Eng. Struct. 2014, 62, 118-134. [CrossRef]

20. Roca, P.; Cervera, M.; Gariup, G.; Pela, L. Structural analysis of masonry historical constructions. Classical and advanced approaches. Arch. Comput. Methods Eng. 2010, 17, 299-325. [CrossRef]

21. Lourenço, P.B. Experimental and numerical issues in the modelling of the mechanical behaviour of masonry. Struct. Anal. Hist. Constr. II 1998.

22. Sarhosis, V.; Lemos, J.V. A detailed micro-modelling approach for the structural analysis of masonry assemblages. Comput. Struct. 2018, 206. [CrossRef]

23. Lemos, J.V. Discrete element modeling of masonry structures. Int. J. Archit. Herit. 2007, 1, 190-213. [CrossRef]

24. Aggiornamento delle "Norme Tecniche per le Costruzioni"-NTC 2018; Ministero delle Infrastrutture e dei Trasporti: Rome, Italy; p. 372.

25. Ferreira, T.M.; Mendes, N.; Silva, R. Multiscale seismic vulnerability assessment and retrofit of existing masonry buildings. Buildings 2019, 9, 91. [CrossRef]

26. Shehu, R. Preliminary Assessment of the Seismic Vulnerability of Three Inclined Bell-towers in Ferrara, Italy. Int. J. Archit. Herit. 2020, 1-33. [CrossRef]

27. Ceroni, F.; Pecce, M.; Voto, S.; Manfredi, G. Historical, architectural, and structural assessment of the bell tower of Santa Maria del Carmine. Int. J. Archit. Herit. 2009, 3. [CrossRef]

28. Marra, A.M.; Salvatori, L.; Spinelli, P.; Bartoli, G. Incremental Dynamic and Nonlinear Static Analyses for Seismic Assessment of Medieval Masonry Towers. J. Perform. Constr. Facil. 2017, 31, 04017032. [CrossRef]

29. Acito, M.; Magrinelli, E.; Milani, G.; Tiberti, S. Seismic vulnerability of masonry buildings: Numerical insight on damage causes for residential buildings by the 2016 central Italy seismic sequence and evaluation of strengthening techniques. J. Build. Eng. 2020, 28, 101081. [CrossRef]

30. DeJong, M.J. Seismic response of stone masonry spires: Analytical modeling. Eng. Struct. 2012, 40, 556-565. [CrossRef] 
31. Shakya, M.; Varum, H.; Vicente, R.; Costa, A. Empirical Formulation for Estimating the Fundamental Frequency of Slender Masonry Structures. Int. J. Archit. Herit. 2016, 10, 55-66. [CrossRef]

32. D'Altri, A.M.; Sarhosis, V.; Milani, G.; Rots, J.; Cattari, S.; Lagomarsino, S.; Sacco, E.; Tralli, A.; Castellazzi, G.; de Miranda, S. Modeling Strategies for the Computational Analysis of Unreinforced Masonry Structures: Review and Classification. Arch. Comput. Methods Eng. 2020, 27, 1153-1185.

33. Degli Abbati, S.; D’Altri, A.M.; Ottonelli, D.; Castellazzi, G.; Cattari, S.; de Miranda, S.; Lagomarsino, S. Seismic assessment of interacting structural units in complex historic masonry constructions by nonlinear static analyses. Comput. Struct. 2019, 213, 51-71. [CrossRef]

34. Milani, G.; Shehu, R.; Valente, M. Seismic Assessment of Masonry Towers by Means of Nonlinear Static Procedures. Procedia Eng. 2017, 199, 266-271. [CrossRef]

35. Parisi, F.; Augenti, N. Uncertainty in seismic capacity of masonry buildings. Buildings 2012, 2, 218. [CrossRef]

36. Amari, K.; Abdessemed Foufa, A.; Cheikh Zouaoui, M.; Uva, G. Seismic Vulnerability of Masonry Lighthouses: A Study of the Bengut Lighthouse, Dellys, Boumerdès, Algeria. Buildings 2020, 10, 247. [CrossRef]

37. Croce, P.; Landi, F.; Formichi, P. Probabilistic Seismic Assessment of Existing Masonry Buildings. Buildings 2019, 9, 237. [CrossRef]

38. Guadagnuolo, M.; Nuzzo, M.; Faella, G. The Corpus Domini Bell Tower: Conservation and Safety. Procedia Struct. Integr. 2018, 11. [CrossRef]

39. Magenes, G. A method for pushover analysis in seismic assessment of masonry buildings. In Proceedings of the 12th World Conference on Earthquake Engineering, New Zealand Society for Earthquake Engineering, Upper Hutt, New Zealand, 30 January-4 February 2000.

40. Pintucchi, B.; Zani, N. Effectiveness of nonlinear static procedures for slender masonry towers. Bull. Earthq. Eng. 2014, 12, 2531-2556. [CrossRef]

41. Simulia, D.S. Abaqus 6.14 documentation 2014.

42. Federal Emergency Management Agency. Prestandard and Commentary for the Seismic Rehabilitation of Buildings; FEMA: Washington, DC, USA, 2000.

43. European Committee for Standardization. Eurocode 8: Design of Structures for Earthquake Resistance-Part 1; CEN: Brussels, Belgium, 2014; Volume 3.

44. Istruzioni per l'applicazione dell' Aggiornamento delle "Norme tecniche per le costruzioni"; Ministero delle Infrastrutture e dei Trasporti: Rome, Italy; Volume 35, p. 337.

45. Goel, R.K.; Chopra, A.K. Role of higher-“mode” pushover analyses in seismic analysis of buildings. Earthq. Spectra 2005, 21, 1027-1041. [CrossRef]

46. Antoniu, S.; Pinho, R. Development And Verification Of A Displacement-Based Adaptive Pushover Procedure. J. Earthq. Eng. 2004, 8, 643-661. [CrossRef]

47. NTC-18 Explicative Notes: Part 8- Costruzioni Esistenti; 2017.

48. Applied Technology Council. Seismic Evaluation and Retrofit of Concrete Buildings; ATC: Redwood City, CA, USA, 1996.

49. Valente, M.; Milani, G. Nonlinear dynamic and static analyses on eight historical masonry towers in the North-East of Italy. Eng. Struct. 2016, 114, 241-270. [CrossRef]

50. European Committee for Standardization. Eurocode 6-Design of Masonry Structures—Simplified Calculation Methods for Unreinforced Masonry Structures. Part 1-1 General Rules for Reinforced Unreinforced Masonry Structures; EN 1996-1; CEN: Brussels, Belgium, 2005.

51. Casolo, S.; Milani, G.; Uva, G.; Alessandri, C. Comparative seismic vulnerability analysis on ten masonry towers in the coastal Po Valley in Italy. Eng. Struct. 2013, 49, 465-490. [CrossRef]

52. Valente, M.; Milani, G. Effects of Geometrical Features on the Seismic Response of Historical Masonry Towers. J. Earthq. Eng. 2017, 1-33. [CrossRef]

53. Giannini, R.; Pagnoni, T.; Pinto, P.E.; Vanzi, I. Risk analysis of a medieval tower before and after strengthening. Struct. Saf. 1996, 18, 81-100. [CrossRef]

54. Bernardeschi, K.; Padovani, C.; Pasquinelli, G. Numerical modelling of the structural behaviour of Buti's bell tower. J. Cult. Herit. 2004, 5, 371-378. [CrossRef]

55. Carpinteri, A.; Lacidogna, G. Damage evaluation of three masonry towers by acoustic emission. Eng. Struct. 2007. [CrossRef]

56. Saisi, A.; Gentile, C.; Guidobaldi, M. Post-earthquake continuous dynamic monitoring of the Gabbia Tower in Mantua, Italy. Constr. Build. Mater. 2015. [CrossRef]

57. Milani, G.; Shehu, R.; Valente, M. Seismic vulnerability of leaning masonry towers located in Emilia-Romagna region, Italy:FE analyses of four case studies. AIP Conf. Proc. 2016, 1790, 130002. [CrossRef]

58. Valente, M.; Milani, G. Seismic assessment of historical masonry towers by means of simplified approaches and standard FEM. Constr. Build. Mater. 2016, 108, 74-104. [CrossRef]

59. Bartoli, G.; Betti, M.; Marra, A.M.; Monchetti, S. Semiempirical Formulations for Estimating the Main Frequency of Slender Masonry Towers. J. Perform. Constr. Facil. 2017, 31, 04017025. [CrossRef]

60. Palermo, M.; Silvestri, S.; Gasparini, G.; Baraccani, S.; Trombetti, T. An approach for the mechanical characterisation of the Asinelli Tower (Bologna) in presence of insufficient experimental data. J. Cult. Herit. 2015, 16, 536-543. [CrossRef]

61. Pesci, A.; Casula, G.; Boschi, E. Laser scanning the Garisenda and Asinelli towers in Bologna (Italy): Detailed deformation patterns of two ancient leaning buildings. J. Cult. Herit. 2011, 12, 117-127. [CrossRef] 
62. Ferraioli, M.; Miccoli, L.; Abruzzese, D. Dynamic characterisation of a historic bell-tower using a sensitivity-based technique for model tuning. J. Civ. Struct. Health Monit. 2018, 8, 253-269. [CrossRef]

63. Lubliner, J.; Oliver, J.; Oller, S.; Oñate, E. A plastic-damage model for concrete. Int. J. Solids Struct. 1989, 25, 299-326. [CrossRef]

64. Lee, J.; Fenves, G.L. Plastic-Damage Model for Cyclic Loading of Concrete Structures. Eng. Mech. 1998, 124, 892-900. [CrossRef]

65. Sarhosis, V.; Milani, G.; Formisano, A.; Fabbrocino, F. Evaluation of different approaches for the estimation of the seismic vulnerability of masonry towers. Bull. Earthq. Eng. 2017, 16. [CrossRef]

66. Heyman, J. Leaning towers. Meccanica 1992, 27, 153-159. [CrossRef] 